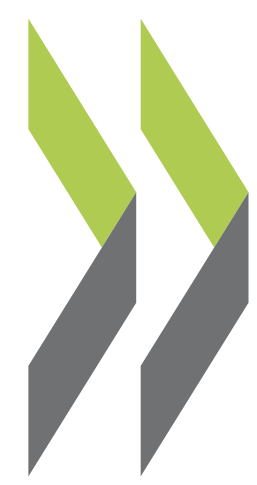

OECD Economics Department Working Papers No. 1011

\section{Reforming Policies}

for the Business Sector

to Harvest the Benefits

of Globalisation in the Netherlands

\section{Mathijs Gerritsen,}

Jens Høj 
Organisation de Coopération et de Développement Économiques

Organisation for Economic Co-operation and Development

14-Jan-2013

ECONOMICS DEPARTMENT

English - Or. English

\section{REFORMING POLICIES FOR THE BUSINESS SECTOR TO HARVEST THE BENEFITS OF GLOBALISATION IN THE NETHERLANDS}

ECONOMICS DEPARTMENT WORKING PAPER No. 1011

By Mathijs Gerritsen and Jens Høj

All OECD Economics Department Working Papers are available through OECD's Internet website at http://www.oecd.org/eco/Workingpapers

JT03333274

Complete document available on OLIS in its original format

This document and any map included herein are without prejudice to the status of or sovereignty over any territory, to the delimitation of international frontiers and boundaries and to the name of any territory, city or area. 


\section{ABSTRACT/RESUME}

\section{Reforming policies for the business sector to harvest the benefits of globalisation in the Netherlands}

The Netherlands has strongly benefited from globalisation, which boosted international trade, crossborder investment and economic growth over the latest decades. Looking ahead, the Netherlands needs to shift the trade and investment orientation from traditional slow-growing markets to faster growing emerging economies, in order to keep reaping the benefits from globalisation. In addition, the ongoing globalisation will push companies to become more innovative and search for new activities. Against this backdrop, the government is reforming its policies for the business sector. This includes a targeted approach, where the government is attempting to strengthen key sectors to become even stronger players on the international scene. This approach, however, carries some of the risks of more traditional industrial policy, making careful policy design and evaluation important elements for successful implementation. The other building block of the new policies is a strengthening of framework conditions, which promises a more market-based development of comparative advantages, and which could be further strengthened by broadening the approach to include other policies, such as competition policies. This Working Paper relates to the 2012 OECD Economic Survey of the Netherlands (www.oecd.org/eco/surveys/netherlands).

JEL classification codes: F6 ; F15, F21

Keywords: Globalisation, Economic Integration, International Investments

$$
* * * * * * *
$$

\section{Réformer les politiques relatives au secteur des entreprises pour récolter les fruits de la mondialisation aux Pays-Bas}

Les Pays-Bas ont fortement bénéficié de la mondialisation, qui a dynamisé les échanges internationaux, les investissements transfrontaliers et la croissance économique au cours des dernières décennies. Dans les temps à venir, les Pays-Bas vont devoir réorienter leurs échanges et leurs investissements, qui sont axés aujourd'hui sur des marchés traditionnels à faible croissance, vers les économies émergentes en expansion rapide, afin de continuer à tirer parti de la mondialisation. En outre, la poursuite du processus de mondialisation va pousser les entreprises à devenir plus innovantes et à rechercher de nouvelles activités. Dans ce contexte, le gouvernement est en train de réformer ses politiques relatives au secteur des entreprises. Cela passe par une approche ciblée, dans le cadre de laquelle les pouvoirs publics s'efforcent de renforcer des secteurs clés pour disposer d'acteurs encore plus forts sur la scène internationale. Cette approche comporte cependant certains des risques inhérents à une politique industrielle de facture plus traditionnelle, de sorte que le soin apporté à l'élaboration des dispositifs et à leur évaluation constituera une condition importante de réussite de leur mise en œuvre. L'autre élément essentiel des nouvelles mesures réside dans une amélioration des conditions-cadre, qui devrait permettre un renforcement des avantages comparatifs davantage fondé sur les mécanismes du marché, et qui pourrait être encore plus poussée si les pouvoirs publics élargissaient cette approche à d'autres domaines de l'action publique, tels que la politique de la concurrence. Ce document de travail se rapporte à l'Étude économique des Pays-Bas de 2012 (www.oecd.org/eco/etudes/Pays-Bas).

Classification JEL : F6, F15, F21

Mots clefs : La mondialisation, l'intégration économique, les investissements internationaux 


\section{TABLE OF CONTENTS}

Reforming policies for the business sector to harvest the benefits of globalisation in the Netherlands..........5

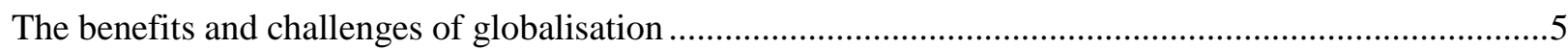

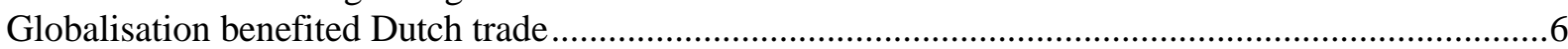

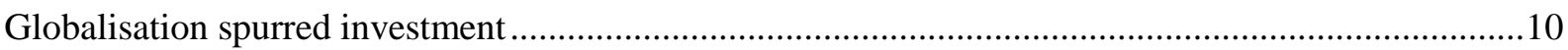

Benefiting from globalisation by strengthening the business environment ........................................13

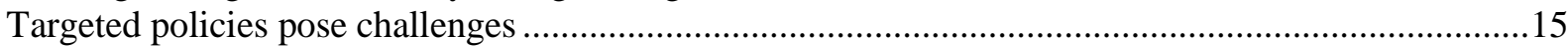

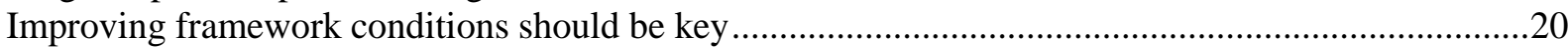

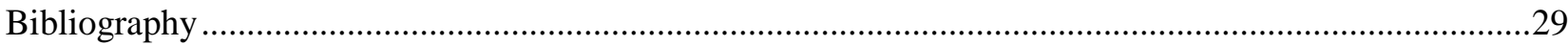

\section{Boxes}

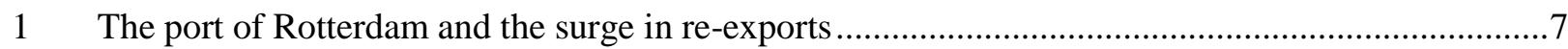

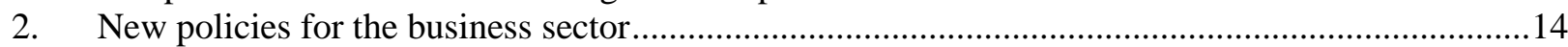

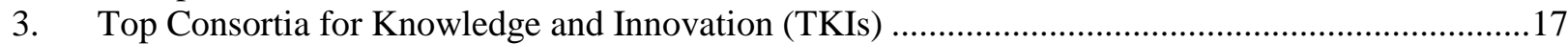

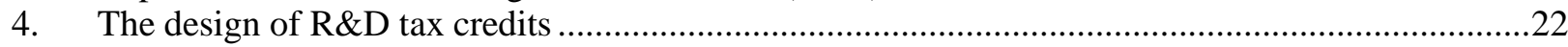

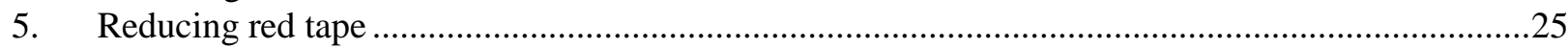

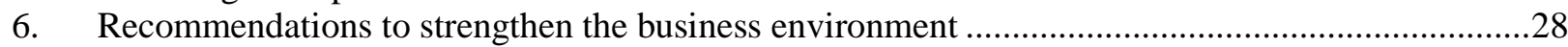

\section{Tables}

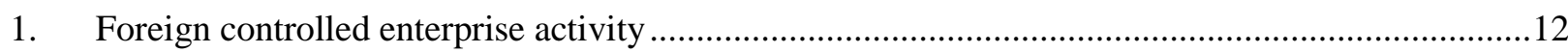

2. The main dates in the formulation of the new policies of the business sector................................14

3. Tax measures to foster innovative activities (main features per scheme) …..................................21

4. Top 10 problematic factors for doing business in the Netherlands ..............................................27

\section{Figures}

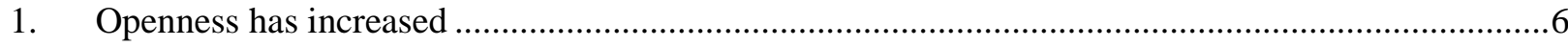

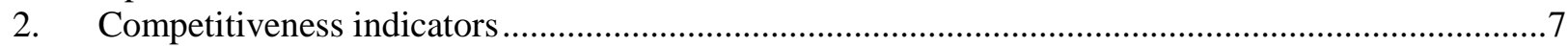

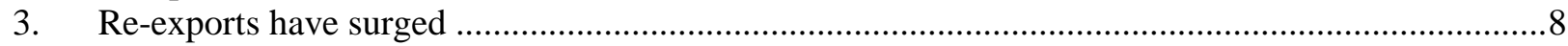

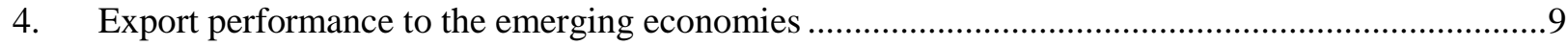

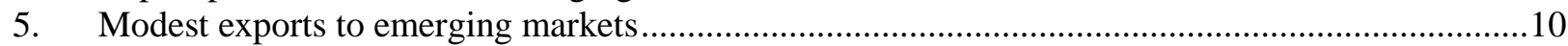

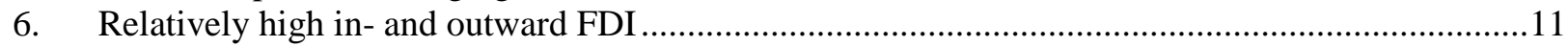

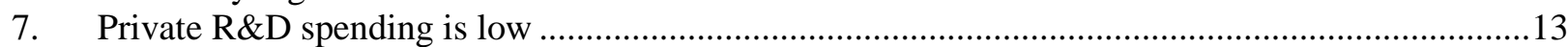

8. Services exports specialised in professional business, communication as well as royalties ............16

9. The share of graduates with a science or engineering degree is low .............................................18

10. High explicit barriers to trade and investment in emerging markets ..........................................19

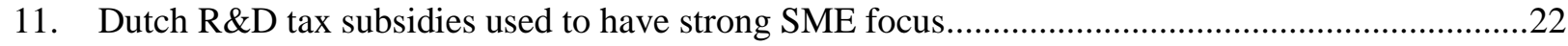

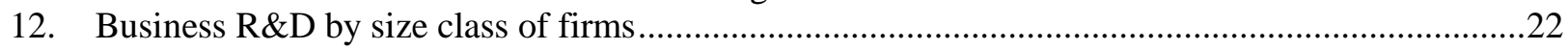

13. Excellent research system but mediocre business linkages ..........................................................24

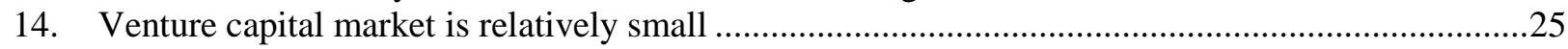

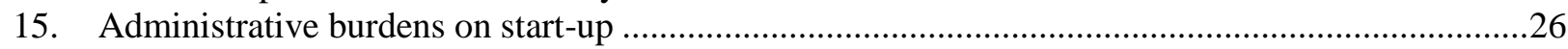

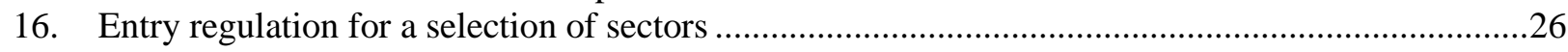

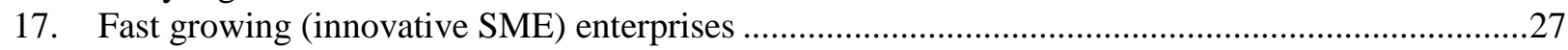


ECO/WKP(2013)3 
ECO/WKP(2013)3

\title{
Reforming policies for the business sector to harvest the benefits of globalisation in the Netherlands
}

\author{
By Mathijs Gerritsen and Jens Høj ${ }^{1}$
}

The economy has been benefiting from accelerating globalisation and technology change. The increase in world trade has allowed the Netherlands to capitalise on Rotterdam's position as the main trade gateway to Europe. Both inward and outward foreign investment has increased, fostering the transfer of new technologies and efficiency-enhancing separation of production - ultimately supporting productivity growth. Moreover, consumers have benefited from downward pressure on prices via cheaper imports from emerging economies and greater choice. However, looking ahead, there is a need to strengthen export and investment linkages with emerging markets, while ongoing globalisation forces companies to innovate and search for new activities in which they can excel - partly as emerging markets quickly move up the value added chain. To capitalise on the opportunities and challenges from globalisation the Dutch government is reforming its policies for the business sector. The main thrust of the new policy approach is: to focus on areas of excellence, particularly in the form of a "top sector approach"; and to improve framework conditions for the entire private sector, referred to as the "economic agenda". The paper first analyses how globalisation has shaped the Dutch economy and identifies major challenges. Then, the paper assesses policies to strengthen the business sector in the context of globalisation and its interplay with other policies. The paper concludes with a set of policy recommendations.

\section{The benefits and challenges of globalisation}

The Dutch position as a trading nation and gateway to Europe has allowed the economy to profit from globalisation for centuries. The golden age in the $17^{\text {th }}$ century benefitted from skilled immigrants, innovations (e.g. the sawmill and freely transferable shares) and access to distant markets (e.g. Japan) allowing the economy to become a world leader (Barbour, 1950; Van Nieuwkerk, 2006). More recently, the latest decades of intensified globalisation has seen lower tariff barriers, technological progress, and a fall in transport and communication costs, which have fragmented production processes and strengthened the economic links to the rest of the world (Figure 1.). ${ }^{2}$

1. Jens Høj is Head of Belgium and the Netherlands desk in the Economics Department of the OECD. Mathijs Gerritsen is an economist at the Dutch Ministry of Economic Affairs. This Working Paper is based on Chapter 1 of the OECD's 2012 Economic Survey of the Netherlands which was prepared under the responsibility of the Economic and Development Review Committee. The author is grateful for the valuable comments received from Andrew Dean, Bob Ford, Pierre Beynet and other colleagues in the Economics Department. Special thanks go to Sylvie Foucher-Hantala for statistical assistance and to Maartje Michelson and Sylvie Ricordeau for secretarial assistance.

2.. $\quad$ Globalisation may be defined as the process whereby domestic product, capital and labour markets become more integrated across borders (OECD, 2007a). 
Figure 1. Openness has increased

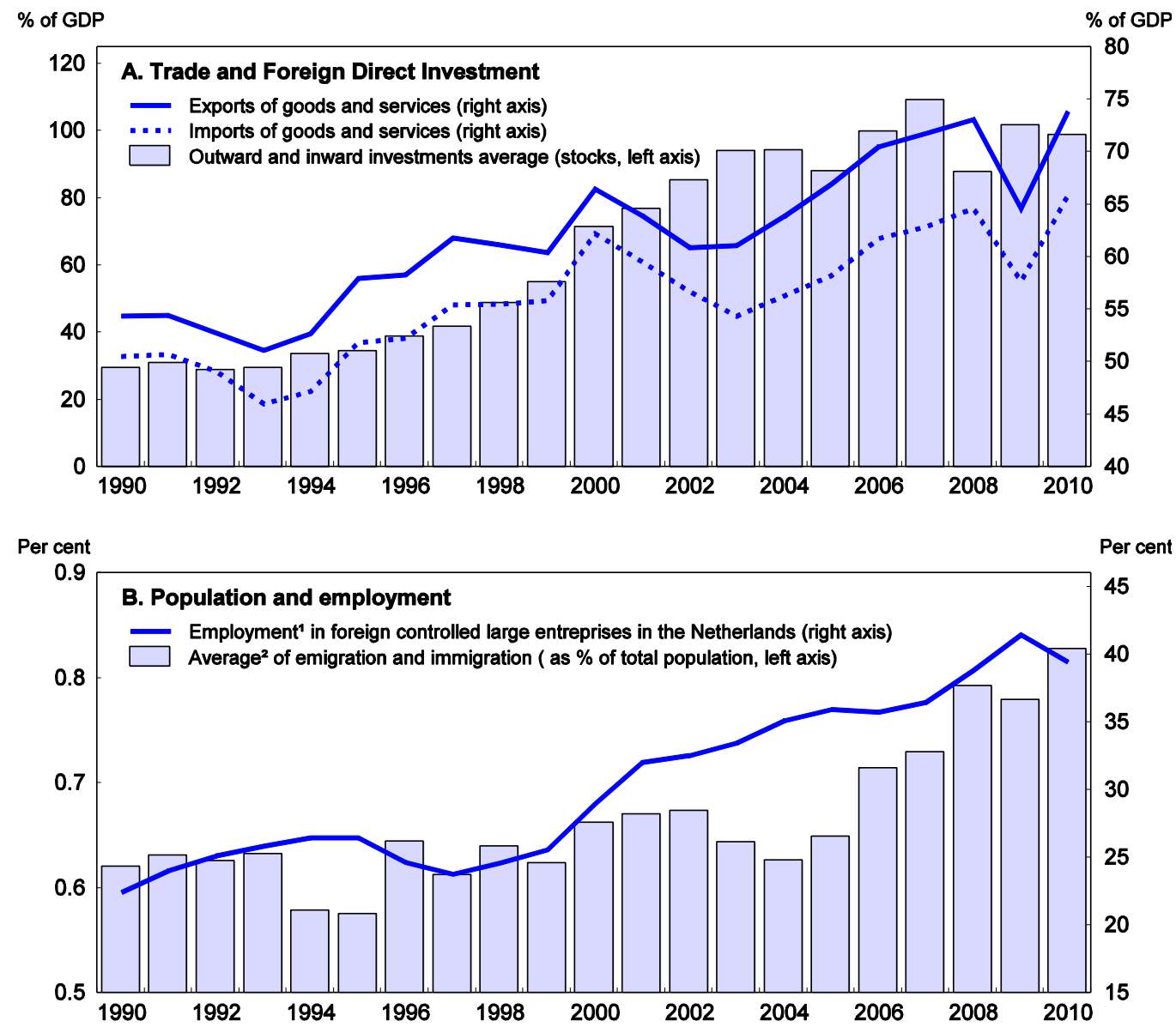

1. 2010 is preliminary data. Full-time equivalents employment as a percentage of total employment in large enterprises in the Netherlands. Based on survey among enterprises with a balance sheet over EUR 23 million, excluding financial sector.

2. Emigration and immigration are measured as flows, population as stocks, all on 31st December. Emigration includes net administrative corrections.

Source: OECD (2012), Economic Outlook and Foreign Direct Investment Statistics databases, CBS - Statline database, March 2012.

\section{Globalisation benefited Dutch trade}

Exports have grown rapidly over the past decades on the back of faster world trade growth and the expansion and deepening of the European internal market. Since the early 1990s, the share of goods exports to GDP has increased from about $40 \%$ to $60 \%$. Trade is highly concentrated with $1 \%$ of firms accounting for more than $70 \%$ of all exports (in value), while only around $11 \%$ of all firms are engaged in export activities (Statistics Netherlands, 2011). The exporting firms have in common that they tend to be larger, more productive and more skill and capital-intensive than non-exporting firms (Bernard et al., 2007; Van Bergeijk et al., 2011). The export market performance for goods has been stronger than in many other OECD countries (Figure 2). This reflects to a large degree a surge in re-exports of goods that often enter through the port of Rotterdam and which receive minor treatment (with value-added that is on average one eight of domestically produced goods) in the Netherlands before being re-exported (Box 1 and Figure 1) (Mellens et al., 2007; Kuypers et al., 2012). Particularly, the transport and logistics sectors are benefiting from this surge in the trade of goods. In this connection, a policy challenge is to ensure that infrastructure capacities keep up with private activity, where a road-pricing scheme would secure an efficient use of existing infrastructure as emphasized in the previous Economic Survey. 
ECO/WKP(2013)3

Figure 2. Competitiveness indicators

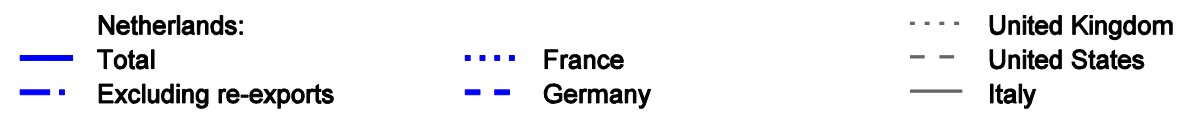

Index, $1991=100$

Index, $1991=100$
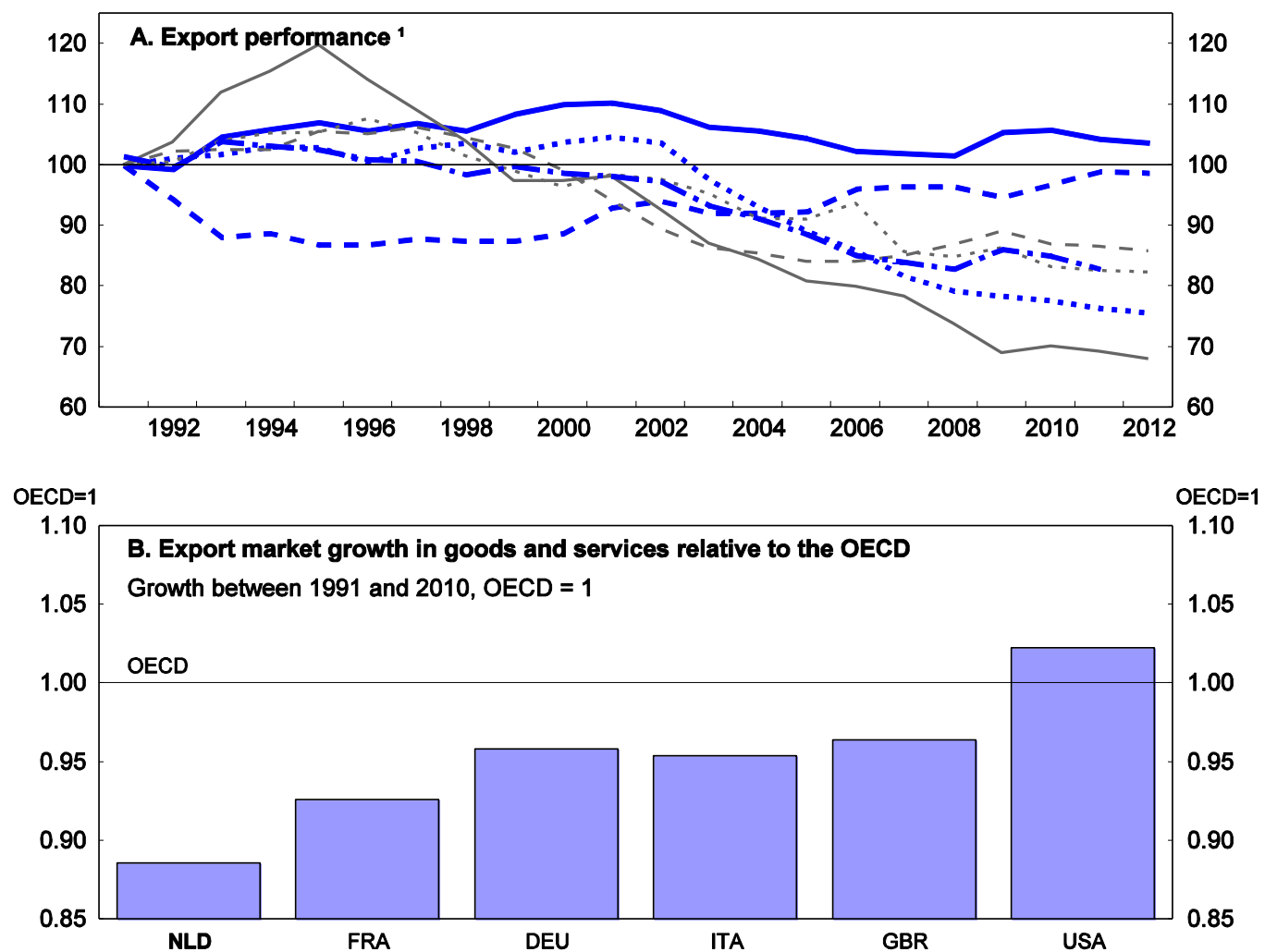

1. Export performance is measured as actual growth in exports relative to the growth of the country's export market.

2. Re-exports according to Dutch classification.

Source: OECD (2012), Economic Outlook database.

\section{Box 1 The port of Rotterdam and the surge in re-exports}

The port of Rotterdam is, by far, the largest seaport of Europe, benefiting from easy access to ships with the deepest draughts. As gateway to the continent, the port and industrial complex stretches over 40 kilometres and covers some 10 thousand hectares. This excludes Maasvlakte 2, which is currently under construction and covers an additional 2 thousand hectares. The port handles about 430 million tons of cargo a year - corresponding to a $40 \%$ market share of North Sea port traffic (ports from Hamburg to Le Havre). Out of more than 18 thousand containers a day, Rotterdam ships on average over 4 thousand containers with China as the country of destination or origin. Reflecting bilateral trade volumes, about $40 \%$ of the containers from Rotterdam to China are empty, against $1 \%$ of the incoming ones.

With an extensive network of hinterland connections - inland shipping, coastal shipping, rail, road and pipelines Rotterdam facilitates the import and export of goods from and to the European market. Containers mainly go by road transport $(57 \%)$, followed by inland shipping $(33 \%)$ and rail transport $(10 \%)$. Besides its role as distribution hub, the port offers facilities for the storage and handling of all kinds of commodities and products, while processing and chemical industries have a strong presence.

For 2008, direct employment within the port and industrial cluster is estimated at about 90 thousand people, and indirect employment (e.g. suppliers, service providers) at 55 thousand. Activities related to the port of Rotterdam correspond to about $4 \%$ of GDP (Van den Bosch et al., 2011). The Port Authority expects economic activity to increase rapidly, reflected by a projected increase of total throughput by up to $74 \%$, to 750 million tons in 2030 . Growth projections are especially strong for container shipment, while dry and liquid bulk handling is expected to grow more moderately. The expected expansion of activities poses considerable challenges related to e.g. spatial planning, the environment and hinterland connection. 
The port of Rotterdam plays an important role in the surge in re-exports. In the Netherlands, these exports are defined as goods that are imported and then leave the country without undergoing much processing. Re-exports represent about half of total exports of goods, and are (contrary to transit trade) included in the trade statistics as soon as a Dutch company temporarily becomes the owner of the goods. Europe is the most important destination with $85 \%$ of all re-exports, which concerns mainly items like machinery, computers, electronic devices and chemical products. The average value added content in re-exports (about EUR 7.5 cents per exported euro) is much lower than domestically produced goods (EUR 58.5 cents). Nonetheless, the surge in re-exports has been an important driver of growth in the Netherlands, accounting in net terms to an annual 0.2 percentage point to GDP growth over the last two decades (Kranendonk and Verbruggen, 2011).

Source: Port of Rotterdam Authority (2011a, b, c); Mellens et al. (2007); Van den Bosch et al. (2011); Kranendonk and Verbruggen (2011); Kuypers et al. (2012).

\section{Figure 3. Re-exports have surged ${ }^{1}$}

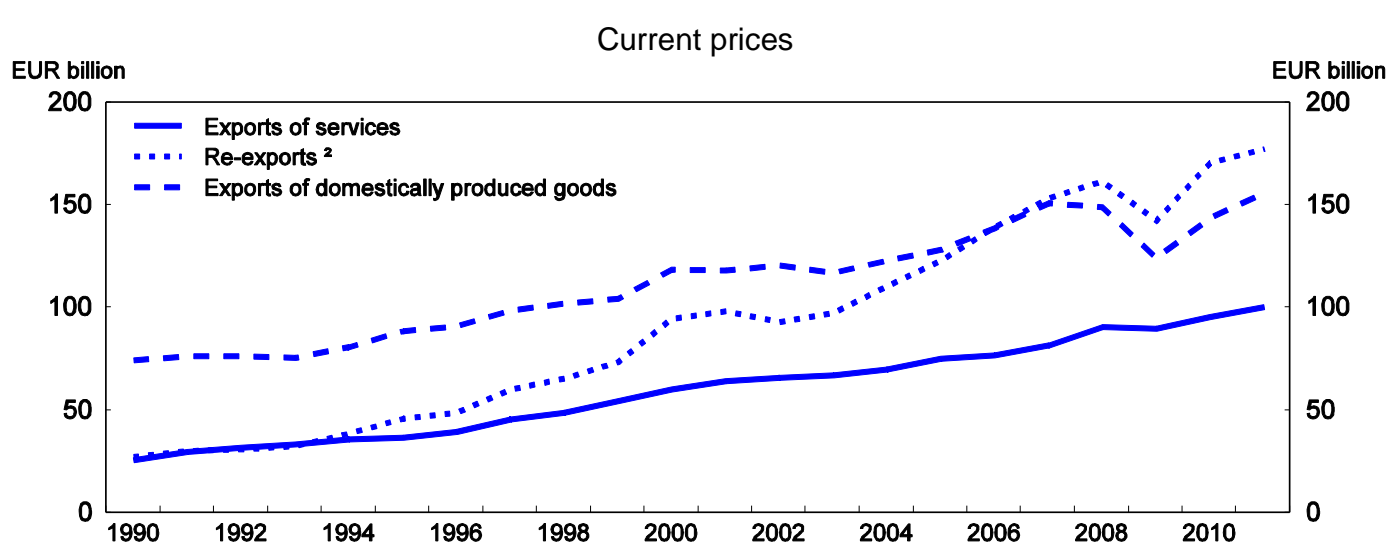

1. Data excludes energy.

2. Re-exports according to Dutch classification.

Source: CPB (2012), CPB Netherlands Bureau for Economic Policy Analysis.

Service trade has increased in line with goods exports, concerning activities like computer and information, financial and transport services. This reflects the increased services content in the economy, ongoing liberalisation of trade and investment, technological developments, as well as a related fragmentation of the international value added chain (OECD, 2005; OECD, 2007a; DNB, 2007). In total, service exports have remained stable at around 20\% of total Dutch exports (Statistics Netherlands, 2011). However, this hides the fact that service trade is often in relatively high value added activities. Nowadays, about $40 \%$ of Dutch value added stemming from exports can be attributed to the exports of services, against 25\% in 1990 (Kranendonk and Verbruggen, 2011).

Dutch exports have benefited from strong import growth in rapidly growing emerging market economies. Even though the Netherlands' market shares in these markets have not increased since the mid 2000 's, they account for an increasing share of total exports (Figure 4). Exports, nevertheless, remain mainly concentrated in traditional and relatively slow growing markets in Europe and North America. Indeed, compared to other OECD countries, the Netherlands exports relatively little to the emerging economies (Figure 5), although distance, the composition of the export structure and the high share of re-exports can partly explain the difference. ${ }^{3}$ The picture is unchanged when taking into account indirect exports to emerging economies (via Dutch goods used as inputs in other countries' exports to the emerging

3. In 2009, $3.8 \%$ of total goods exports had Brazil, Russia, India or China (BRIC countries) as destination, against $4.3 \%$ of domestically produced exports goods (Statistics Netherlands, 2010c). 
economies) (Groot et al., 2011a). ${ }^{4}$ Given the more dynamic long-term economic outlook of emerging economies, it is important to secure better export penetration in these countries. However, doing business in emerging markets is relatively complicated, e.g. due to cultural differences, regulatory barriers (to trade and FDI), discriminatory procedures and government involvement in economic activity, which could justify public intervention.

Figure 4. Export performance to the emerging economies

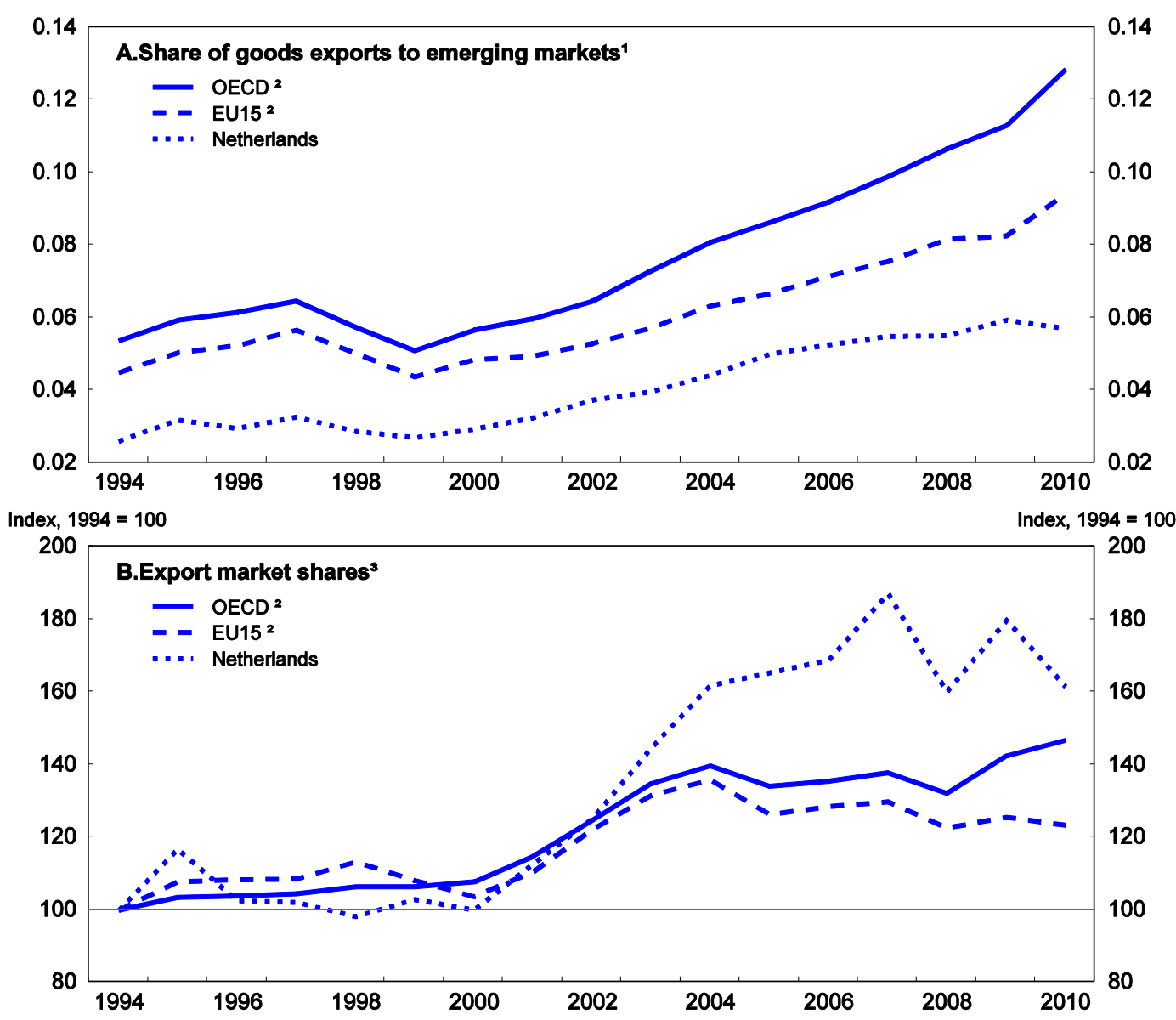

1. Exports to Brazil, Russia, India, Indonesia, China, South Africa and Turkey over total exports.

2. OECD excludes Turkey. Estimated data for Slovakia between 1994 and 1997, and for Luxembourg between 1993 and 1999.

3. Exports over emerging markets total imports.

Source: OECD, ITCS database and IFS.

4. A notable exception is the export of services: about $6 \%$ of Dutch services exports find their way to the BRIC countries, compared to about $5.5 \%$ for the OECD as a whole. 
Figure 5. Modest exports to emerging markets

Exports of goods to BRIC countries ${ }^{1}$, as percentage of total , 2010 or latest year available

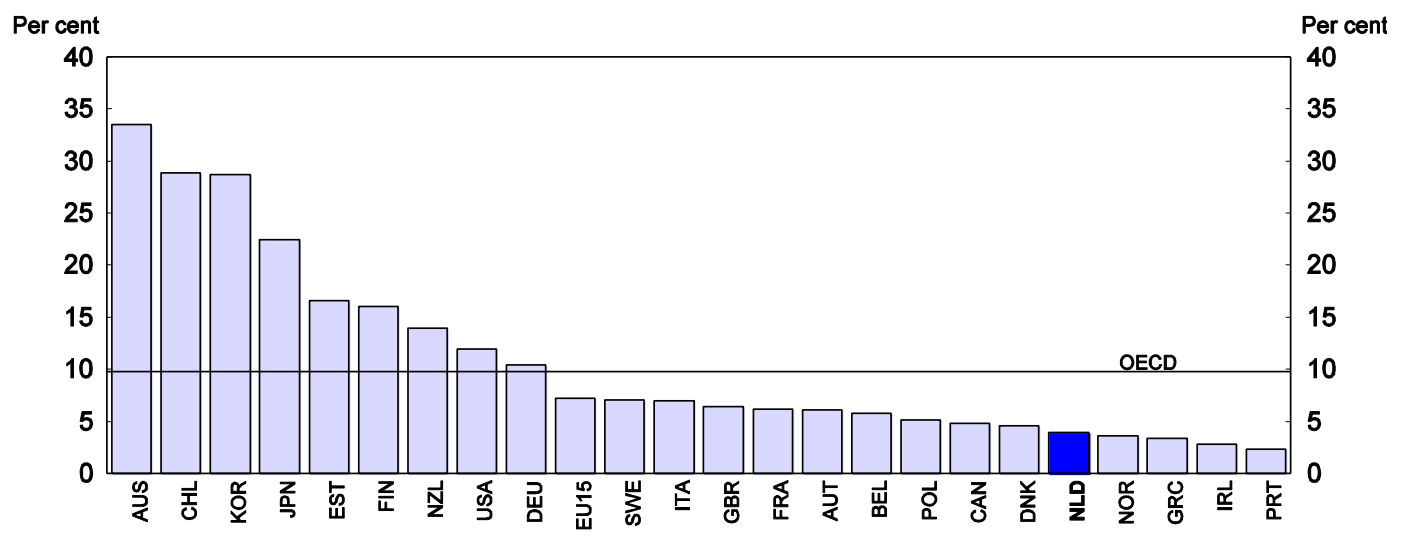

1. Total goods exports to BRIC countries as a percentage of total goods exports of presented countries.

Source: OECD (2012), International Trade and Commodities Statistics database.

An important positive effect of globalisation is the increase in consumer welfare through greater choice of goods and lower prices (Groot et al., 2011b; Pain et al., 2008; Suyker et al., 2007). In addition, companies benefit from lower prices of intermediate goods. The share of goods imports from emerging economies has increased rapidly since 1990, particularly from China, and competition from low-cost foreign suppliers has dampened domestic inflation pressures. Conservative estimates suggest that globalisation has reduced Dutch inflation up to 0.3 percentage points per annum in the period 2000-05 (Pain et al., 2008). This calculation includes the emerging economies' role in the surge of energy and commodity prices. Looking ahead, the effect of globalisation on inflation is likely to weaken as the emerging markets converge towards more advanced economies, although the effect on choice should persist.

\section{Globalisation spurred investment}

Foreign direct investment (FDI) in the form of acquisitions and greenfield investment (i.e. opening a new subsidiary) have increased rapidly over the last few decades to the highest level in the OECD when measured by the value of inward and outward FDI positions. However, for the Netherlands, about threequarters is accounted for by Special Purpose Entities, i.e. subsidiaries of foreign parent companies that function as financial turntables, benefit from the favourable Dutch tax regime and hardly affect the real economy (DNB, 2008; DNB, 2011; Statistics Netherlands, 2011). ${ }^{5}$ Subtracting these, the share of in- and outward FDI remains relatively high (Figure 6). The inward FDI fosters technology spill-over, innovative activities as well as capital deepening and enhance competitive pressures on domestic firms (Nicoletti et al., 2003; Gelauff et al., 2010). Foreign affiliates account for a relatively large share of value-added, investment and turnover and, to a lesser extent, employment (Table 1). In addition, these enterprises are more innovative and productive and pay higher wages than domestically controlled counterparts (Statistics Netherlands, 2008; 2009; 2010a). Indeed, foreign controlled enterprises account for about a third of R\&D investments and half of total trade (Statistics Netherlands, 2010a; 2010b). However, a small part of the

5. The favourable tax regime concerns the relatively low statutory corporate tax rate, the possibility of advance tax ruling to give certainty about the level of taxation, the broad tax treaty network, a favourable "participation exemption" regime, and a zero statutory withholding tax rate on outbound royalty payments, among others (Top team Head Offices, 2011; NFIA, 2011). 
inward FDI comes from emerging markets. ${ }^{6}$ This might be influenced by the often very vocal public debate erupting in case of foreign takeovers - often centred on risks of job losses - despite that empirically such takeovers have little or no impact on employment growth in subsequent years (Urlings et al., 2011). ${ }^{7}$

Figure 6. Relatively high in- and outward FDI

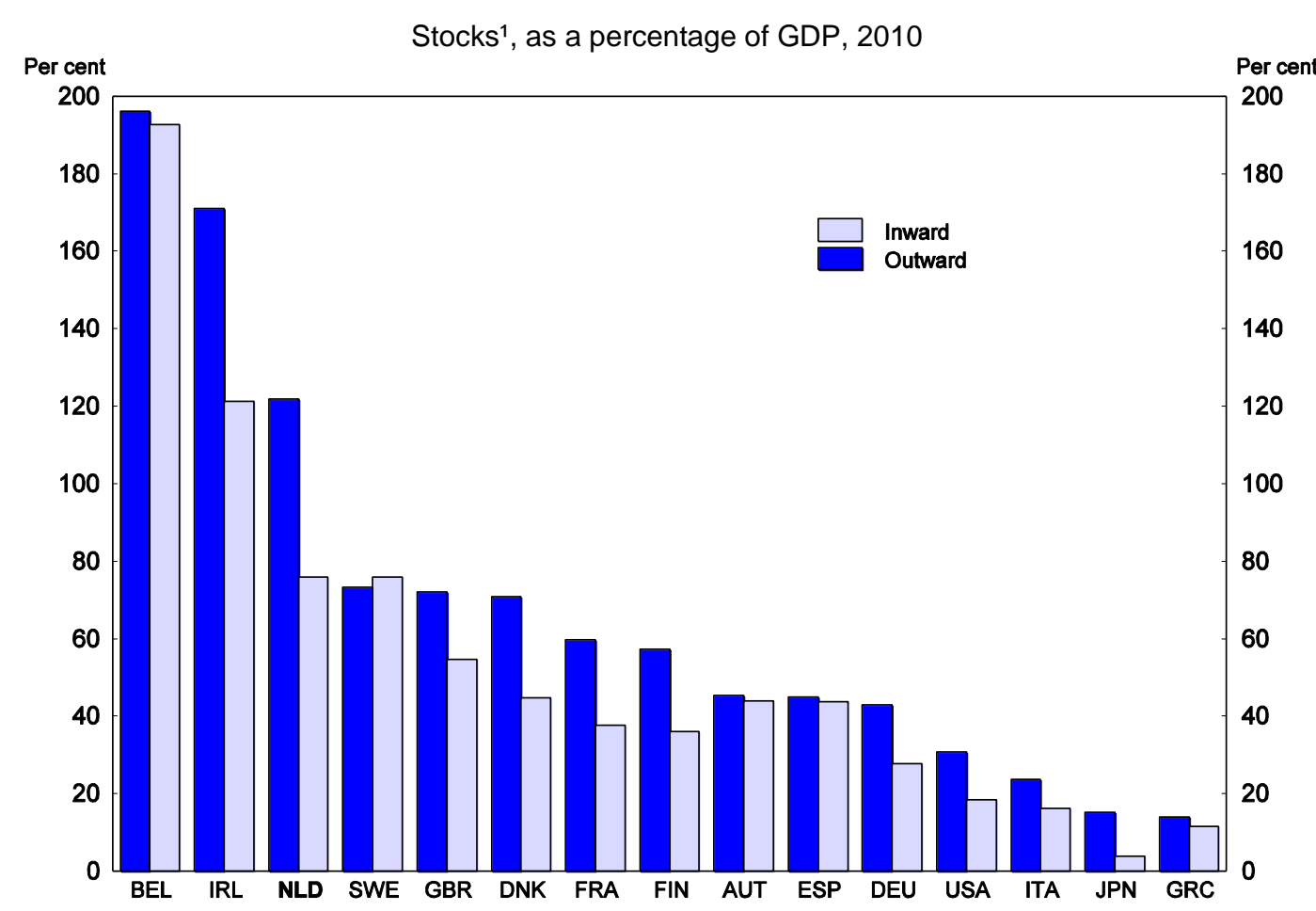

1. Excluding Special Purpose Entities (SPEs) for Austria, and Netherlands.

Source: OECD (2012), International Direct Investment Statistics and National Accounts of OECD Countries - online databases, February.

6. Although FDI data do not suggest a substantial establishment of firms from emerging market economies in the Netherlands, micro data in firm ownership indicate that the Netherlands seem to be an attractive location in Europe for firms with their origin in the BRIC countries. The latter could be related to the large distribution and logistics sectors (Groot et al., 2011b).

7. An unfortunate development is the sometimes less positive public and political approach towards the acquisitions of Dutch companies by foreign parties, especially when the investors find their origin in non OECD countries. See, for instance, the discussions surrounding the acquisition of ECT by Hutchinson Whampoa in 1999, Hoogovens/Corus by Tata Steel in 2007 and the attempted takeover of Draka by Xinmao in 2011. 
Table 1. Foreign controlled enterprise activity

$\%$ total private sector activity (except financial and insurance activities) of country, 2008

\begin{tabular}{lccrrrrr}
\hline & Netherlands & France & Germany & Finland & Denmark & $\begin{array}{c}\text { Sweden } \\
\text { Everage }\end{array}$ \\
\hline Number of enterprises & 1.0 & 0.7 & 1.1 & 1.0 & 1.6 & 1.9 & 1.1 \\
Number of persons employed & 14.0 & 12.6 & 12.0 & 15.7 & 15.3 & 22.5 & 14.2 \\
Value added at factor cost & 24.4 & 19.5 & 20.2 & 19.4 & 24.2 & 26.9 & 20.7 \\
Gross investment (tangible goods) & 21.8 & 7.5 & 19.1 & 12.6 & 16.2 & 22.7 & 17.2 \\
Turnover & 31.4 & 21.8 & 26.7 & 20.9 & 23.9 & 32.5 & 24.9 \\
\hline
\end{tabular}

1. Unweighted, excluding Netherlands, available countries.

Source: Eurostat, Inward FATS.

The outward FDI position is even larger - mirroring the country's sustained current account surplus. Investment takes mainly place in other advanced economies, whereas the share in emerging markets is limited. Outward FDI allows firms to serve foreign markets and enhance the efficiency of production as well as helping multinationals to build global R\&D networks to tap into local knowledge and develop new technologies (OECD, 2007a). Outward FDI also reflects the outsourcing of production, mostly to European countries although Asia is also a popular destination with about $30 \%$ of outsourcing activities (Statistics Netherlands, 2011). The labour market effect of outsourcing is modest; most studies find that relatively few jobs are involved in international outsourcing, especially compared to regular job turnover (e.g., Gorter et. al., 2005; Heyma and Theeuwes, 2008). In particular, there appears to be no substantial difference between unemployed workers from off-shoring and non-off-shoring industries in terms of unemployment duration, reemployment probability and subsequent wages (Heyma and Theeuwes, 2008). A relatively new development is that outsourcing is increasingly affecting highly-skilled employees and services (OECD, 2005; Van Gorp, 2008 and 2010). Thus, looking ahead, outsourcing may expose a greater share of the work force to international competition, increasing the need for reallocation of workers across and within sectors (OECD, 2012).

Globalisation, including stronger international competition, forces companies to innovate. In addition, as the population ages (OECD, 2012) economic growth must increasingly come from innovation-induced productivity growth. However, private R\&D spending is well below the OECD and EU 15 averages and has been declining over the past decade (Figure 7) (Court of Audit, 2011). ${ }^{8}$ The persistently low R\&D ratio mirrors the difficulties various policies have had in boosting private $R \& D$ activities, though it can partly be linked to the specialisation of the Dutch economy in relatively less R\&D intensive industries, particularly in services (Erken and Ruiter, 2005; EIM, 2011; Schmidt-Ehmcke and Zloczysti, 2011). Moreover, little is known about the relative effectiveness and efficiency of various public innovation schemes (Government, 2010; CPB, 2010; Lanser and Van der Wiel, 2011), calling for greater reliance on "evidence-based policy making", i.e. putting more emphasis on monitoring and evaluations to guide policies.

8. Country rankings of innovation performance - that take into account a wide range of indicators to capture a country's performance both on the output and input side of innovation - usually show the Netherlands in the middle to upper range of OECD / EU countries. See the Synthetic Innovation Indicator by Rae and Sollie (2008); the Innovation Union Scoreboard by the European Commission (2012) and the innovation pillar of the Global Competitiveness Index by the World Economic Forum (2011). 
Figure 7. Private $R \& D$ spending is low

Business enterprise expenditure on research and development, as a percentage of GDP

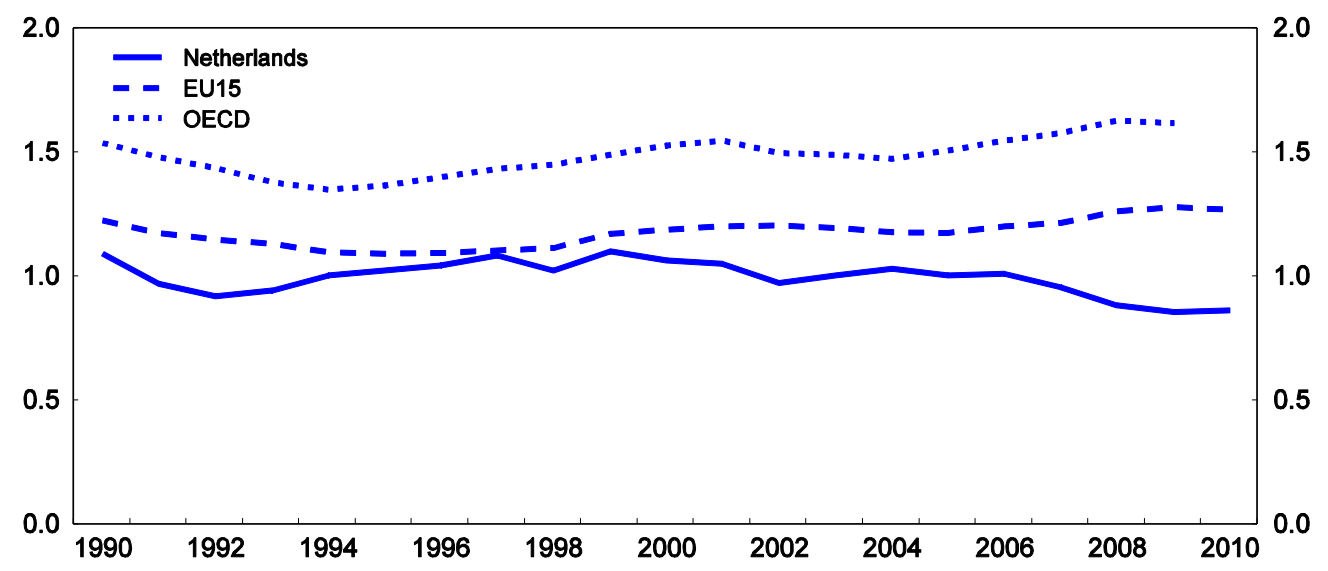

Source: OECD (2012), Main Science and Technology Indicators database.

Globalisation is set to continue and the Netherlands has, as discussed above, profited considerably from the associated opportunities. This has been supported by factors such as a well-educated labour force, a strong business environment, sound access to other markets, and existing agglomeration and location advantages. In addition, there has - so far - been limited overlap between the revealed comparative advantages of the Netherlands and emerging countries (Groot et al., 2011b; Rae and Sollie, 2008; SER, 2008). However, companies may face tougher competition in the future from emerging economies, as these are quickly moving up the value-added chain. Indeed, the integration of these new players is challenging existing comparative advantages of countries, forcing companies to search for new activities in which they can excel and to enhance their productivity by being more innovative (OECD, 2007a). At the same time, the likely shift in global economic activity, notably towards Asia and Latin America, makes it important to establish strong export and investment positions in these new zones of economic activity. In all, it is important that policies for the business sector are continuously evaluated and updated to address these challenges.

\section{Benefiting from globalisation by strengthening the business environment}

The government seeks to improve the competitiveness of the business sector, meet the challenges from globalisation, and boost innovative activities by implementing a new policy for the business sector (Box 2) (Ministry of EL\&I, 2011a; 2011b; 2012). The policy combines targeted support with an improvement in general framework conditions, and consists of two main planks. One plank is a broad "economic agenda" with a focus on framework conditions to reduce the regulatory burden, strengthen the innovation framework, and improve access to risk capital. ${ }^{9}$ The other plank is a targeted "top sector approach" focussing on nine key sectors in the economy. The rationale for the new policy is to address information asymmetries and coordination failures by linking the business sector, knowledge institutions and the government. Indeed, a key feature is strong private sector involvement to facilitate demand driven policies. The policy is still being developed.

9. Other elements - which are outside the scope of the present discussion - include the improvement of spatial economic conditions for economic clusters (e.g. related to the port of Rotterdam and Amsterdam Schiphol airport), and the application of information and communication technology (ICT). 


\section{Box 2. New policies for the business sector}

In February 2011, the government presented a new policy to foster business sector competitiveness' and prepare the economy to face challenges and opportunities from globalisation. In addition, the new policy intends to help to address economic and social goals related to population ageing, climate change and pressure on global resources. Specifically, the government has set three targets: to be one of the top five knowledge economies in the world by 2020 (using the World Economic Forum as a yardstick); increase R\&D spending to $2.5 \%$ of GDP (currently $1.8 \%$ of GDP); boost public-private cooperation in knowledge and innovation activities to more than EUR $1 / 2$ billion by 2015 (Ministry of Economic Affairs, Agriculture and Innovation, 2011b).

The new policy has two planks: an "economic agenda" for the entire private sector and a "top sector approach" with specific attention to nine economic sectors of the economy. In February 2011, the general framework and ideas were outlined, after which an interactive process between public and private stakeholders progressively specified the new policies (Table 1.2). Important building blocks are the demand driven approach - policies are mainly based on input from the private sector - the reduction in innovation subsidies in exchange for tax credits, broader access to corporate finance, and fostering the clustering of economic and research activities. Moreover, an important element is the stronger reliance on "evidencebased policy making", i.e. putting more emphasis on monitoring and evaluation to guide policies. Against the backdrop of the need to consolidate public finances, the fiscal scope of the new enterprise policies is limited (gradually increasing to about $0.3 \%$ of GDP by 2015), and mainly involves a reallocation of different existing outlays to support business and innovative activities.

The economic agenda involves a range of policies to improve the business environment for the entire private sector. It aims to cut substantially the administrative and regulatory burden. In addition, subsidies for innovative activities are largely being replaced by tax credits and an investment fund has been created to provide innovation credits and seed capital, mainly for starting, innovative and/or rapidly growing SMEs. Moreover, the agenda intends to foster the application of new knowledge in products or processes, increase the use of ICT and improve spatial economic conditions for economic clusters (e.g. related to the port of Rotterdam and Schiphol airport), among others.

For the top sector approach the government has identified nine economic sectors (agro-food, crops, water, high-tech, life sciences, chemicals, energy, logistics and the creative industry) plus "headquarters" (for internationally operating firms) as key areas of competence, where investments should be prioritised and bottlenecks identified. According to the government, these sectors are knowledge intensive, export-oriented, usually with specific legislation and regulation, and could make an important contribution to solving societal issues. In total, an annual EUR 1.5 billion ( $0.2 \%$ of GDP) is to be (re-) allocated to the top sectors by 2015.To facilitate a demand driven "bottom-up" process, multidisciplinary teams (the so-called "top teams") were formed for each top sector. The teams include sector experts (typically well-known business figures), a high-ranking civil servant, an SME entrepreneur and a representative from a research institution. The tasks of the teams were to identify opportunities and challenges for the respective sector and formulate proposals to address sector-specific problems, mainly related to research and innovation, foreign policy, sector specific regulation, and education/ human capital. Besides having identified sector specific bottlenecks, the teams stressed that some of the challenges ask for (a top sector) overarching policies (e.g. related to elements of education, innovation, and availability of risk capital), thereby further shaping the economic agenda relevant to the entire private sector. The first interactive phase of establishing objectives and policies has mostly been finalised, while implementation is gradually taking place.

\section{Table 2. The main dates in the formulation of the new policies of the business sector}

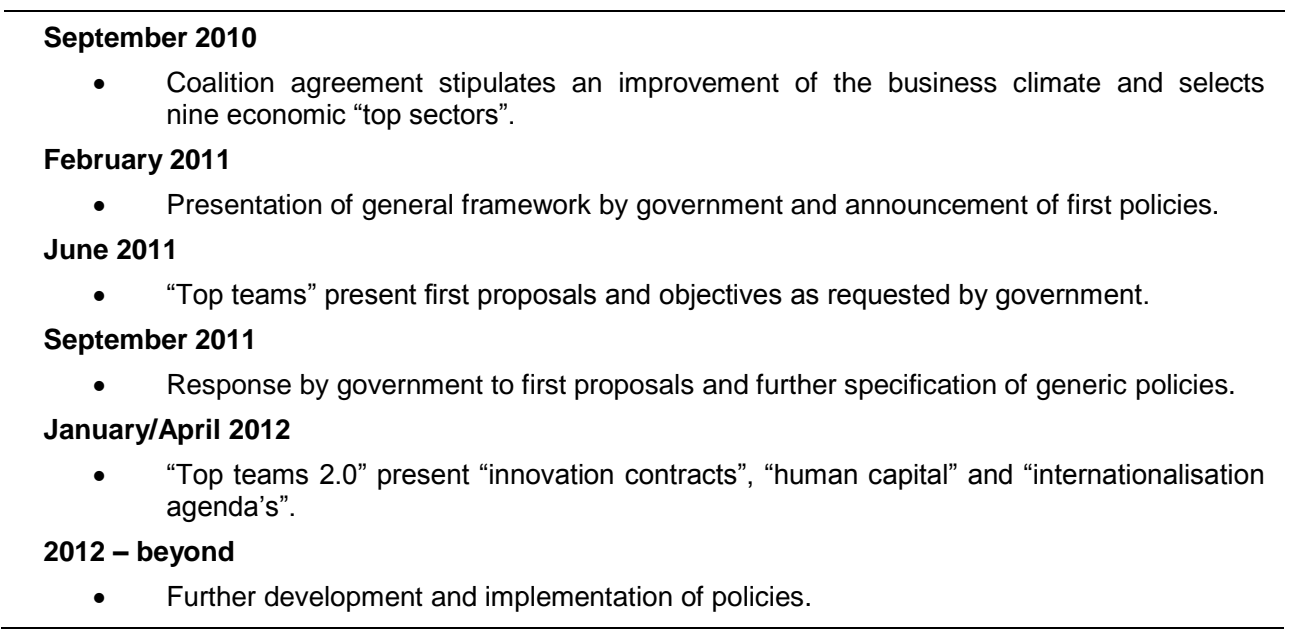

Source: Ministry of Economic Affairs, Agriculture and Innovation, 2011a; 2011b; 2012. 
An important issue in the literature is to what extent such policies can strengthen the economy. An improvement of general framework conditions can foster innovation and productivity performance, allowing market forces to shape comparative advantages over time. More controversial is the role for targeted intervention supporting specific sectors or activities (Naudé, 2010a). Targeted support could be justified by positive externalities (e.g. knowledge spillovers via economic clustering or innovation in clean technology), information asymmetries (e.g. leading to capital market imperfections) and coordination failures (e.g. lack of coordination between different actors that leads to underinvestment in projects with high initial costs) (Rodrik, 2008; Lin and Chang, 2009; Aghion et al., 2011; OECD, 2011a). However, targeted support also has potential drawbacks, such as wrong sector selection and rent-seeking behaviour from economic agents (Rodrik, 2008; Lin and Chang, 2009; Naudé, 2010a and 2010b). Hence, insofar as more targeted interventions are successful in correcting market failures they should benefit the economy, though it is a policy challenge to design governance procedures to detect and correct market failures and manage vested interests. Moreover, it is important to recall that national economies do not "compete" like corporations (Krugman, 1994). If industrial policy succeeds in altering comparative advantages by increasing activity in promoted sectors, it will also draw economic resources away from other sectors without necessarily boosting overall economic performance. In this respect, a possible pitfall is that governments often lack the information and capability to select and promote the sectors that may have a latent comparative advantage.

\section{Targeted policies pose challenges}

While having abandoned old-style industrial policies in the 1980s, the Netherlands is moving to an alternative form of targeted support. The rationale is to address market and government failures at the sector level for nine areas of expertise as well as to prioritise research and development activities in these "top sectors"- i.e. agro-food, crops, water, high-tech, life sciences, chemicals, energy, logistics and the creative industry, plus "headquarters" (for internationally operating firms). These failures are particularly a limited knowledge transfer from universities, a coordination failure among different branches of the government, overly detailed sector regulation, and an insufficiently supply of skilled workers. The selection criteria included the sectors that are knowledge-intensive and export-oriented, usually with sector-specific regulation, and that can potentially make an important contribution to solving societal issues (Ministry of Economic Affairs, Agriculture and Innovation, 2011b).

The top sector approach follows up on earlier initiatives - mostly in the area of innovation - that aimed to strengthen the competitiveness of roughly the same sectors of the economy (Court of Audit, 2011). However, the new approach is to be broader and more integrated, covering different aspects of the business environment related to sector specific regulation, innovation, human capital and internationalisation. Another important new element is that the private sector has been leading and shaping the new policies. This demand driven approach was facilitated by the creation of "top teams" for each sector, which typically included a well-known business figure, a high-ranking civil servant, an SME entrepreneur and a representative from a research institution. The government asked the teams to identify opportunities and challenges for the respective sector and subsequently formulate agendas to address sector-specific bottlenecks, notably related to research and innovation, human capital, regulation and internationalisation, both at the government level and by the sectors themselves. Moreover, the new approach stipulates a move towards more "evidence-based policy making", by using targets, monitoring and evaluations to guide policies in the different top sectors.

The demand driven process is commendable as it could help address policy makers' information constraints. Indeed, to design effective policies governments need to elicit information from the market, which often requires close cooperation between different private and (semi) public stakeholders - tough in the discussion with the private sector it is a challenge to sufficiently involve SMEs and notably innovative start-up firms that may face very different bottlenecks than incumbents (Rodrik, 2008). In addition, the 
focus on evidence-based policy making is a welcome move as it is key in the design of sound industrial policy and likely to support accountability for the successes and failures of it. In this respect, very clear criteria for success and features such as conditionality, sunset clauses, programme reviewing, and benchmarking should be developed (OECD, 2011a; Rodrik, 2008).

Gauging the overall size and scope of the selected sectors is difficult as the sectors are not strictly defined and sometimes overlap (Koster and Edzes, 2011). In addition, as the individual top sectors are relatively broad and often encompass completely different industries (e.g. logistics could include services as diverge as road haulage, air transport and taxis to warehousing and packaging), it is unclear to what extent all relevant industries are indeed covered and represented by the top sector approach. This complicates the linking of instruments and objectives as well as the general move to "evidence-based policy making". Hence, to ensure an efficient use of public funds and enable evidence-based policy making by linking instruments and objectives, the scope of the top sectors should become more clearly defined.

The selected top sectors are to a large extent representing the traditional manufacturing sectors, while the presence of services is relatively limited. This seems somewhat counterintuitive given the large services content in the economy, their role as an important input for the manufacturing sector and the importance of services exports, which make the services sector key to fully reap the benefits from globalisation (Figure 8). Hence, as a mean to identify sector bottlenecks and further improve sector regulation, the government should consider establishing similar teams (or alike initiatives) for other sectors, notably in the service sectors, without necessarily making them top sectors.

Figure 8. Services exports specialised in professional business, communication as well as royalties ${ }^{1}$

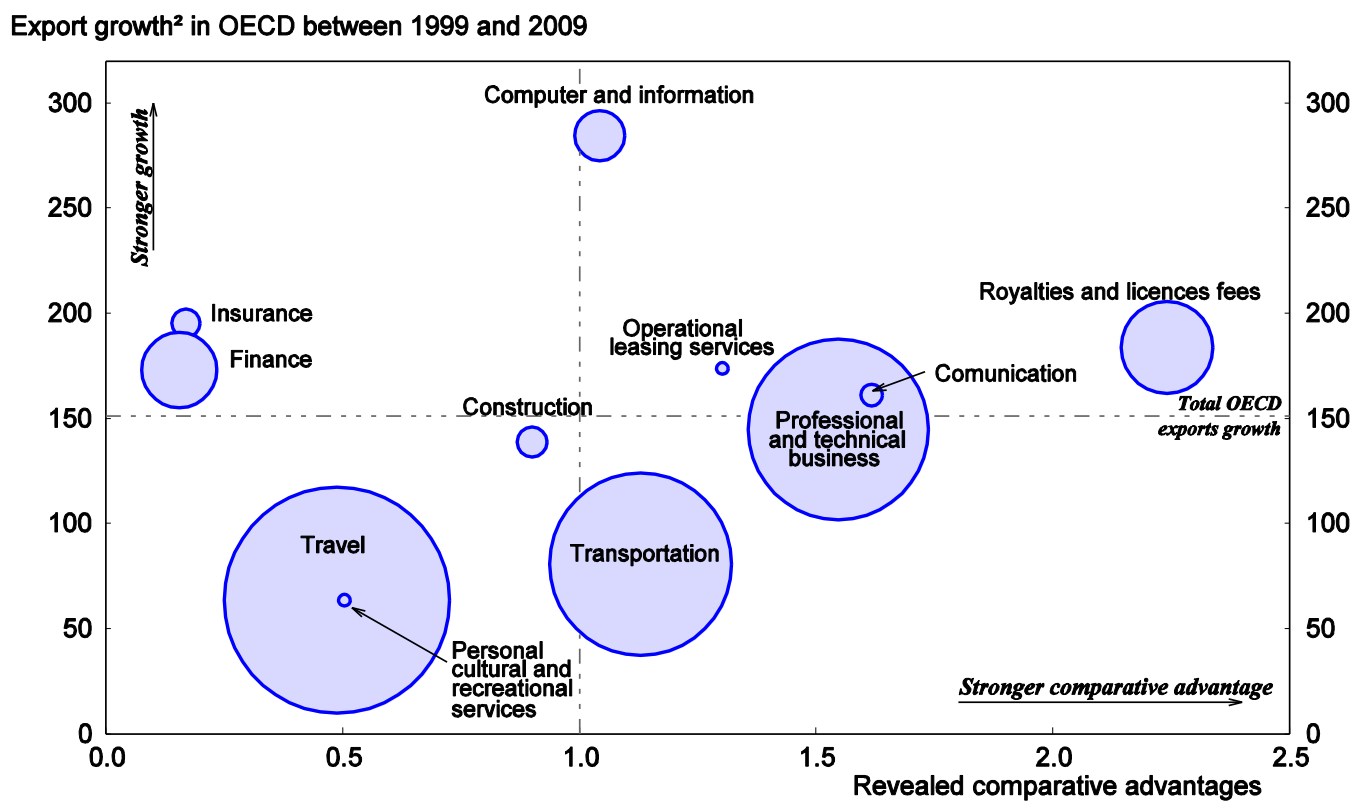

1. The graph shows the relative export specialisation of the Netherlands compared to other OECD countries (for which data are available). The RCA (or Balassa) index of revealed comparative advantage is a measure of a country's export market share of a services category compared to the world's (here OECD) export share of that category. A value above 1 suggests that a country is relatively specialised in the category. The bubbles give an indication of the size of the total (OECD) export market: the bigger the bubble the bigger the size of the export market. The high value of royalties and license fees is likely to reflect the position of the Netherlands as a financial turntable (e.g. the Netherlands has also a high import share in this category).

2. Growth of export market calculated in nominal USD.

Source: OECD, Trade in services database. 
In addition, to capitalise on new opportunities from globalisation, the top sector approach should remain open to accommodate rising sectors or industries in the future, reflecting changes in comparative advantage over time. Similarly, the approach should be able to let structurally declining sector go, which may be politically more difficult. To this respect, a swift and broad implementation of the planned move towards evidence-based policy making would facilitate future sector selection.

Research and innovation are to be strengthened via "innovation contracts" for the top sectors. The contracts are based on public private partnership agreements at the sector level, aiming at reaching a balanced mix of fundamental research, applied research and the application of knowledge in private activity. The top teams developed different research projects for the innovation contracts that fulfil their sector's need for which about EUR 1 billion of public support was made available from already existing (partly from fundamental and applied) research activities. Hence, there are no additional public resources available, but part of them is now explicitly allocated to the top sectors and private sector demand is given a larger role in the work of the research institutions. Moreover, long-term partnership between industry and research bodies within top sectors is promoted via a planned additional tax credit for participation in Top Consortia for Knowledge and Innovation (TKIs) (Box 3). In the context of scarce public resources, the prioritisation of research activities in the areas of the top sectors could be justified, insofar as these earmarked activities are to create relatively large positive (knowledge) spillovers. However, the government should ensure that the earmarked activities do not become a vehicle for favouring particular industries or firms within the different top sectors. A particular concern is that larger firms and existing industries are better organised than SMEs and emerging industries, and can thus gain from a "first-mover" advantage in dealing with public support schemes. A balanced approach can be achieved by requiring that findings from the top teams are backed up by independent evidence and that their policy prescriptions are evaluated against alternatives.

\section{Box 3. Top Consortia for Knowledge and Innovation (TKIs)}

The establishment of Top Consortia for Knowledge and Innovation (TKIs) is an important element of the innovation contracts to secure long-term public-private research cooperation. The TKIs build on already existing initiatives in some sectors (i.e. the virtual "Technologische Top Instituten" or Leading Technological Institutes), where several research and private parties work on demand driven fundamental and strategic research as well as the application of scientific knowledge in processes (see the 2006 Survey for a more detailed description). As the institutes are generally considered to successfully foster long-term public-private research cooperation, the idea is to introduce similar institutes in other sectors. Being under construction, the exact scope and form of the TKls is likely to vary among the top sectors, while some sectors might have more than one consortium to sufficiently cover sector's activities.

To foster participation in TKIs, a fiscal incentive on R\&D activities is to be put in place as of 2013 (see below), and comes on top of the generic tax credits to support R\&D. Thereby, the government makes an exception in the approach that R\&D support should be provided via broad framework conditions. Although the exact format of the tax credit has yet to be determined, the government plans to allocate EUR 90 million on an annual basis, which needs to benefit enterprises as well as knowledge institutions like universities. The government's vision is that more than EUR 0.5 billion will be involved in the TKIs by 2015 , of which at least $40 \%$ will be financed by the business sector

The top teams proposed more plans than are possible with available public funding. The final allocation is being partly determined by the private sector's own contributions (EUR $1 \frac{1}{2}$ billion, mostly based on letters of intent). However, it remains to be seen whether the new approach leads to additional private R\&D activities. The demand driven approach may encourage companies to provide additional funds as research becomes more oriented towards their needs. On the other hand, there is also a risk that the new format crowds out current private R\&D activities as companies bring in-house research activities under the innovation contracts to benefit from associated public support. 
The top teams also prepared education and training agenda to strengthen the link between education and the top sectors' human capital needs (Rae and Sollie, 2008; Baldwin, 2006). The proposed initiatives focus on fostering qualification of pupils, life-long learning and linkages between supply and demand of human capital. Thereby, the top teams suggested putting stronger (financial) incentives in place to stimulate studies that are considered more valuable to the private sector and society (Government, 2012). Specifically, there is a strongly perceived shortage of employees with a science and technology background - including lower skilled technical staff. However, it is hard to find strong evidence of a skill gap in this area (Jacobs and Webbink, 2004; Noailly et al., 2005; De Graaf et al., 2007). For instance, this group of workers only have an average entry salary and they have not seen their relative wages increase over time despite the decreasing supply of workers in the area of science and technology (Figure 2). In addition, more than half of the workers trained in this area work in other economic sectors (Cornet et al., 2006). These findings suggest that the shortage is smaller than perceived, or impediments in the wage formation process that prevent wages to sufficiently reflect relative shortages.

Advice was also sought from the top teams about how to reduce the regulatory burden at the sector level. Such involvement helps to pinpoint market (and government) failures. However, it could also lead to regulatory capture and too much heterogeneity in regulation across sectors, making it potentially harder for investors, including foreign ones, to identify and comply with Dutch sector regulation. This would weaken the positive effects of the attempt to reduce the administrative burden for the entire private sector by $20 \%$ (see below). For instance, some sectors consider the income threshold to allow foreign qualified workers (OECD, 2012) to be too high, thereby acting as a sector specific bottleneck. However, such a bottleneck should be addressed at the general level (i.e. not at the sector level) to avoid too much heterogeneity in regulation across sectors. Hence, the establishment of the top teams is a welcome move to address sector bottlenecks, but it is important this does not lead to unnecessary differences in regulation across sectors.

Figure 9. The share of graduates with a science or engineering degree is low

As a percentage of total new degrees in 2008

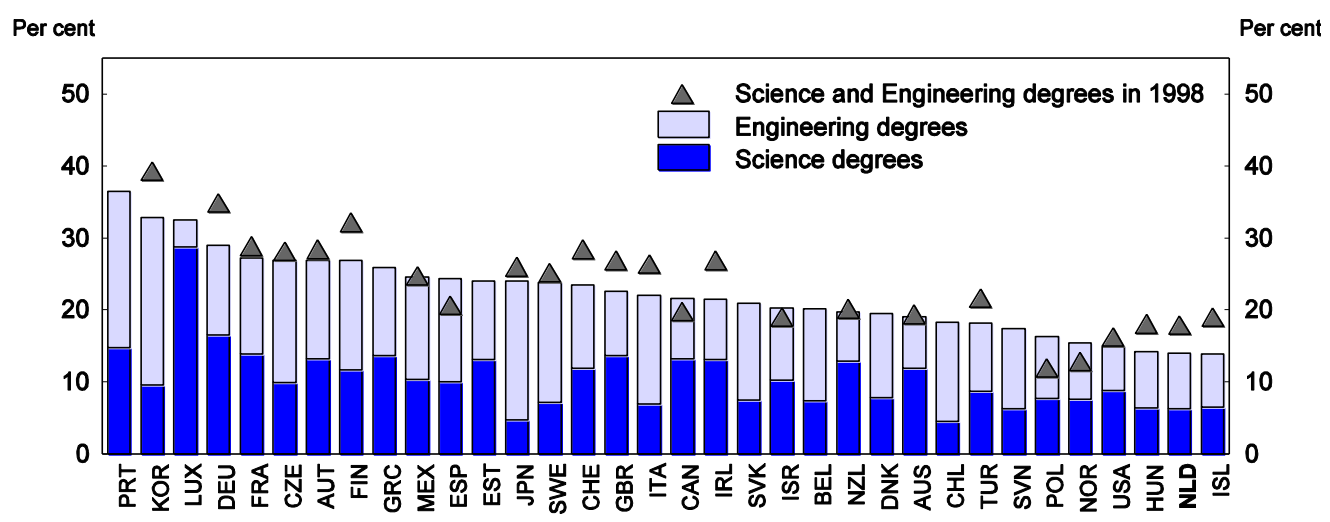

1. Data includes tertiary type-A degrees and advanced research programmes (ISCED 5A and 6).

Source: OECD (2012), Education database, March.

Support for internationalisation of firms is to be given via "economic diplomacy". This involves activities like trade missions, providing advice and information for doing business abroad as well as removing barriers to international trade and investment. Activities in this area are already well established, but the new approach gives more attention to establishing business links with (larger) emerging economies (with again a focus on the nine top sectors), increasing the number of internationally operating SMEs, and attracting (high-tech) FDI from emerging markets (Ministry of Economic Affairs, Agriculture and 
Innovation, 2011a, 2011b and 2011c). ${ }^{10}$ Foreign representations are mobilised to support internationally operating firms. Most services are provided at a fraction of provision costs, though at times a private contribution in the order of EUR 250-500 is in place.

The rationale for economic diplomacy is the existence of market failures, e.g. related to positive international knowledge spillovers, incomplete markets or enforceability of property rights (Harris and $\mathrm{Li}$, 2005; Veenstra et al., 2010). Indeed, doing business in emerging markets is complicated by linguistic, cultural, bureaucratic and political issues, explaining why exporting firms often move slowly to the most distant markets (Creusen and Lejour, 2011). In addition, firms are subject to information problems. This concerns particularly SMEs, as they tend to have relatively small information-networks and gathering capacity (Figure 10). For the Netherlands, empirical work points to economic diplomacy as an effective tool to remove impediments to international trade and investment (e.g. Van den Berg et al., 2008; Creusen and Lejour, 2011; Moons and Van Bergeijk, 2011). ${ }^{11}$

\section{Figure 10. High explicit barriers to trade and investment in emerging markets}

From 0 least restrictive to 6 most restrictive, $2008^{1}$

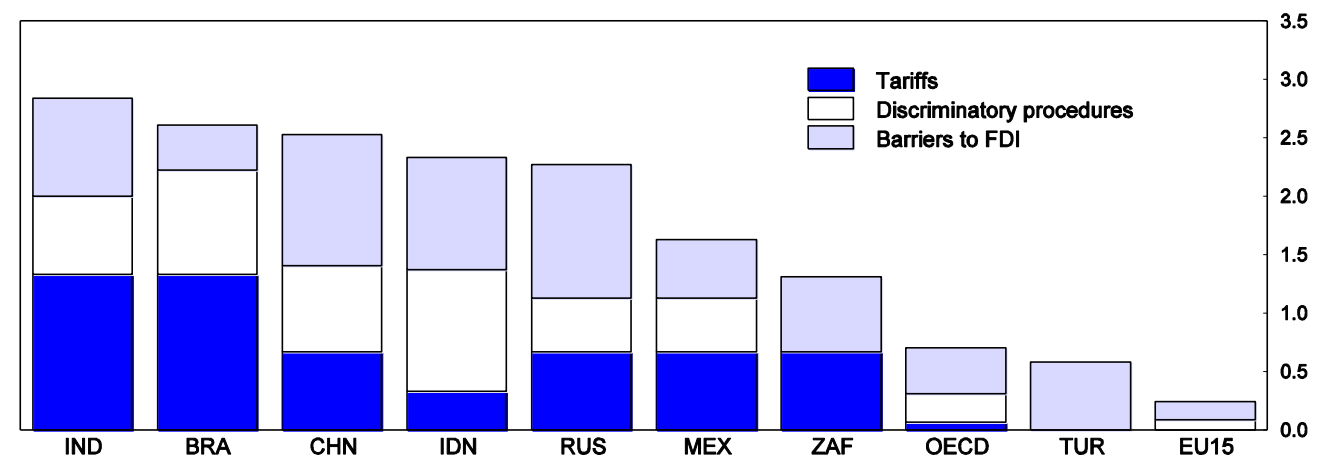

1. IND refers to India and IDN to Indonesia.

Source: OECD (2012), International Trade and Commodities Statistics database.

The increased emphasis on economic diplomacy, notably on doing business with emerging markets, is likely to support trade and investment linkages with the increasingly important players in the world market. However, Dutch exports are concentrated in a small number of larger firms that can generally enter and expand in foreign markets without specific government support. Hence, economic diplomacy efforts that support these firms could displace similar private efforts without boosting internationalisation. In addition, this is an area where developing evidence to form policy is important, as little is known about the costefficiency of the different elements that support the internationalisation of firms. In any case, to secure the cost-efficient use of scarce public resources, it is important that the prices for these services reflect some of the costs. For example, the Danish Trade Council's hourly charge is EUR 120 and the council is subject to

10. Furthermore, part of the programs for international development cooperation will be linked to the areas of the top sectors.

11. However, some instruments appear to be more effective than others. For instance, the presence of embassies and high level trade missions appear to create stronger results than other policy instruments. 
a cost coverage target of $25 \%$, which together with customer satisfaction evaluations aims at securing relatively efficient demand driven activities. ${ }^{12}$

\section{Improving framework conditions should be key}

Over the last two decades, the main focus of industrial policy in the Netherlands has been the improvement of framework conditions, which is reflected in low barriers to entrepreneurship (Wölfl et al., 2009; and WEF, 2011). However, weaknesses remain in the Netherlands' ability to respond to globalisation. These include the relatively low innovation activity, the limited number of fast growing innovative SMEs and entry and exit barriers that hamper economic growth via the process of "creative destruction". The government intends to improve framework conditions for the entire private sector via the economic agenda part of the new policies for the business sector.

Public expenses on stimulating R\&D is projected to increase from EUR 3.2 billon ( $0.5 \%$ of GDP) in 2008 to about 4 billion in 2015 (0.6\% of GDP) (Ministry of EL\&I, 2011d). ${ }^{13}$ To increase innovative activities, various direct innovation subsidies will be replaced by $R \& D$ tax incentives. The fiscal costs of the tax incentives are projected to more than double over the government's term, partly reflecting the doubling in the number of schemes (Table 3). These costs are partly offset by lower direct subsidies to innovation and lower spending on applied research institutions. Another important element of the adjusted innovation framework is the stronger focus on "evidence-based" policy, which follows up on the 2006 Survey recommendation, to enable evaluation of policies. Implementing such monitoring and measuring the effects of innovation policies is difficult, but at least the establishment of some indicators and individual targets per policy instrument could better guide innovation policies.

The policy shift towards tax incentives and evidence-based innovation policy may improve the business environment, make innovation policies simpler and strengthen policy guidance. The shift could make the system more effective, as empirical studies show that tax incentives tend to have a relatively higher impact on private innovation than direct R\&D subsidies, although at the cost of subsidising activities that would have been undertaken anyway (Jaumotte and Pain, 2005; OECD, 2010a) (Box 1.4). Tax incentives have the advantage that they can potentially benefit all firms, reduce the temptation to "pick winners" and are more flexibility regarding the range of R\&D activities undertaken (OECD, 2006a). ${ }^{14}$ Additionally, in the context of the growing internalisation of R\&D activities, stronger tax incentives might also attract R\&D activities of multinationals. ${ }^{15}$ Finally, the new innovation policy reduces the strong focus on SMEs, which used to receive five times more direct subsidies per invested $R \& D$ euro than larger firms, despite the lack of a correspondingly sized market failure to justify such a strong focus (Government, 2010; CPB, 2010) (Figures 11 and 12).

12. Some (basic information) services are free of charge, or against discount rates (usually applied to SMEs with fewer than 50 employees and with a maximum annual turnover of less than DKK 50 million).

13. Spending of central government, i.e. excluding local governments.

14. In general, $R \& D$ tax incentives are found to contribute to $R \& D$ investment, innovation output and welfare in a country, although the responsiveness is greater in the long run and the empirical evidence is scattered (OECD, 2011b).

15. Although other factors such as market access and the country's knowledge base tend to be more important (OECD, 2011b). 
Table 3. Tax measures to foster innovative activities (main features per scheme)

Fiscal costs in 2015

Promotion of Research and Development Act ("WBSO “, existing scheme)
Tax credit for wage costs of employees directly involved in R\&D activities.
- Reduces company wage tax and social security contributions (or income tax if self
employed).
- Deduction of $42 \%$ of the first EUR 110 thousand in R\&D wage costs (2012). And of $14 \%$
- Tor the remaining R\&D wage costs.
- relatively benefitting SMEs.
- In case of under- or overshooting of the estimated fiscal costs, the \% deductibility will be
- Directly improves liquidity positions of companies.

RDA scheme (New scheme: part of the new policies for the business sector)

Tax credit for non-salary expenses and investment in R\&D (e.g. consumables and R\&D equipment).

- Reduces corporate tax payments (or personal income tax if the company is not listed).

- Deduction of $40 \%$ of R\&D costs (2012), implying a net benefit of $10 \%$ (given the corporate tax rate of $25 \%$ ).

- Tax benefit not capped, implying that the RDA tax credit serves SMEs and large companies equally well.

- In case of under- or overshooting of the estimated fiscal costs, the \% deductibility will be adjusted accordingly in the next year.

- If there is no taxable income, the credit can be carried forward or backward in time.

$\boldsymbol{R D A}+\mathbf{s c h e m e}$ (New scheme: part of the new policies for the business sector)

Tax credit to promote public private partnership in Top Consortia for Knowledge and Innovation (TKIs).

- Measure still to be specified (before budget 2013).

- Only for the identified "Top sectors" of the economy.

Innovation box (existing scheme)

0.6

Tax incentive for corporate income derived from patented know how, or R\&D activities under the WBSO scheme.

- Over this income the corporate tax rate is $5 \%$ (instead of $25 \%$ ).

- Tax incentive not capped.

- No adjustment in case of over- or undershooting of the estimated fiscal costs ("open ended" policy).

Total

Source: Ministry of Economic Affairs, Agriculture and Innovation (2011d); Agentschap NL; Dutch tax administration; Authorities. 


\section{Box 4. The design of R\&D tax credits}

R\&D tax credits can be part of a balanced policy mix to increase innovation. Their benefit relatively to direct R\&D subsidies is that they can potentially benefit all R\&D activities, ensuring a more market-based selection of research projects. On the other hand, tax credits are not targeted, which means that the government cannot use such credits to steer research resources into areas with (perceived) high social returns. Moreover, tax credits involve significant deadweight losses in the sense that they notably support research projects that would have been undertaken anyway. Finally, tax credits tend to benefit incumbent firms more than young SMEs, which often lack taxable income to take advantages of tax reliefs.

The deadweight loss could be partly addressed by making R\&D tax incentives incremental, i.e. being based on the increase in R\&D activity, rather than volume based (applied to all R\&D spending). For instance, combining volume and incremental tax incentives would support the level of R\&D investment and reward higher investment growth. However, incremental-based support systems are relatively complex to design and implement: a reason why most OECD countries are moving towards volume-based incentive schemes.

Source: OECD (2011b), Criscuolo et al. (2009), Jaumotte and Pain (2005).

Figure 11. Dutch R\&D tax incentives have strong SME focus

Tax subsidies rate for USD 1 of R\&D, 2008

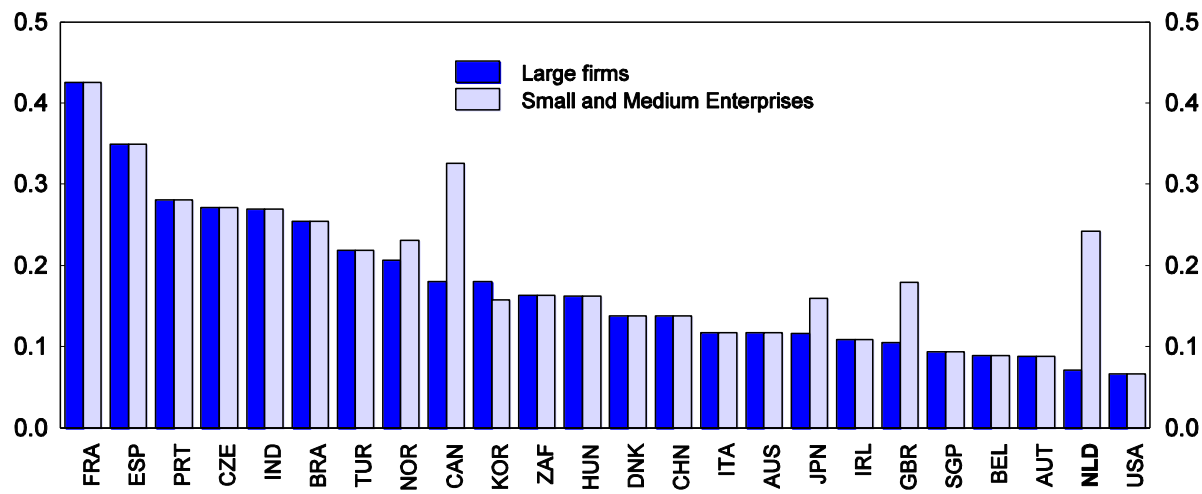

Source: OECD (2009), OECD Science, Technology and Industry Scoreboard 2009.

Figure 12. Business R\&D by size class of firms

As a percentage of total BERD, 20091

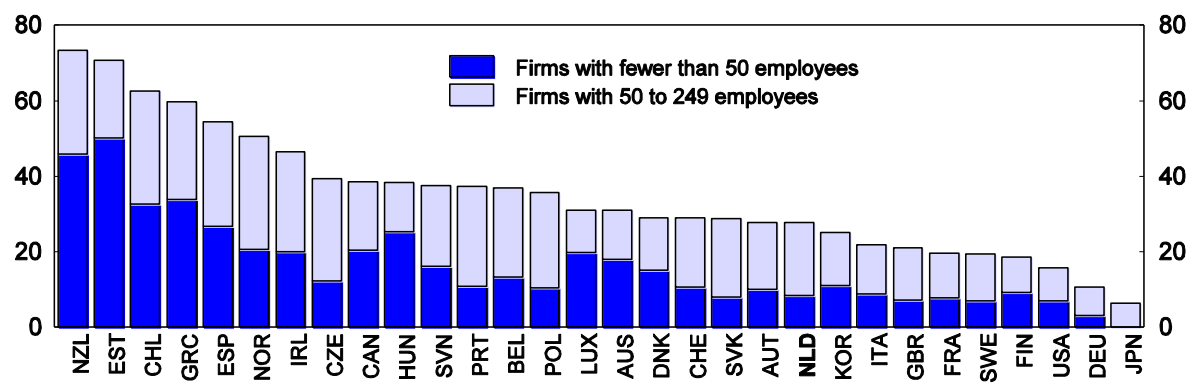

1. Or latest year available. 2008 for Australia, Canada, Chile, France, Korea, Portugal, Poland, Switzerland and United Kingdom. 2007 for Austria, Belgium, Germany, Italy, Luxembourg, Spain, Sweden, and United States. 2005 for Denmark, New Zealand and Ireland. Small firms (fewer than 50 employees): for the United States, 5-49 employees; for Luxembourg, the Netherlands and Sweden, 10-49 employees. Medium-sized firms (50-249 employees): for Japan, fewer than 299 employees. For Japan, the survey excludes firms with a capital of less than 10 million yen.

Source: OECD (2011), OECD Science, Technology and Industry Scoreboard 2011. 
Dutch innovation policies have often shifted over time. For example, the 2006 Economic Survey reported a shift from generic towards more specific support for business R\&D - an approach that is now being reversed. Such policy volatility may damage $R \& D$ activity since expectations that $R \& D$ incentives are permanent should strengthen R\&D investment (Guellec and Van Pottelsberghe de la Potterie, 2003). This point to the need for long-term political commitment to the new R\&D support framework. By the same token, the new policy increases the number of $R \& D$ tax incentives from two to four, possibly raising company transaction costs and increasing overlap and interaction between the schemes. Hence, the policy framework could be further broadened by reducing the number of $\mathrm{R} \& \mathrm{D}$ tax credits.

The government's ambitious goal to boost R\&D spending from $1.8 \%$ to $2.5 \%$ of GDP depends strongly on raising private sector spending, given that public spending is to remain broadly stable in relation to GDP. The policy goal might gradually become more difficult to attain over time as the services content of the economy is likely to increase further, as the R\&D intensity of the services sector is relatively low. It should also be noted that the new innovation framework is focussing on "traditional" R\&D activities, such as science and technology research. However, globalisation is likely to increase the value of investing in other innovative activities, such as new approaches to design, databases, marketing and organisational structures (OECD, 2010b; OECD, 2011c). In fact, investment in such intangible assets is likely to become increasingly important for service-oriented economies.

To complement the innovation policy approach, the 2006 Economic Survey showed that business application of new knowledge is only average, notwithstanding a very strong research system (Figure 13). The government intends to make greater use of private demand to direct university research by allocating $2.5 \%$ of public research funds to convert knowledge into applied innovations and by strengthening the monitoring of the application of public knowledge. However, while an agreement for this purpose between the government and the universities has been outlined, university staff has few personal financial incentives (e.g. in salary scales or shared patent rights) to cooperate with firms on innovation projects. As stressed in the 2006 Survey such incentives are important to strengthen science-business linkages. Hence, to enhance researchers' incentives to market the results of their research, clear and more generous rules for sharing patent rights should be established.

Structural funding bottlenecks for young innovative and fast growing SMEs hamper innovation and growth (Boot and Schmeits, 2004; Ministry of EL\&I, 2011e; AWT, 2011). As in other OECD countries, these issues are mostly related to information problems - on the part of the entrepreneur or among the financers of innovative SMEs - as well as the dominance of traditional banking finance in the Netherlands (OECD, 2006b). Consequently, these SMEs have limited access to risk capital. The associated restricted growth of innovative SMEs means that the economy is not fully capitalising on this important driver of employment creation and productivity growth (OECD, 2010d; AWT, 2011; Bos and Stam, 2011). Moreover, young innovative SMEs have a higher probability to come up with radical innovations contributing to the process of "creative destruction" (Stam and Gerritsen, 2009).

The government is creating a new SME+ Innovation fund to back innovative and fast growing SMEs as an umbrella for different (partly existing) finance schemes in this area (Ministry of EL\&I, 2011a and 2011b). This fund aims at avoiding interferences in the segments of the private market that work appropriately. The fund, with an annual budget of EUR 120 million, has three pillars. The first is direct credits for R\&D projects, which are converted into subsidies in the case of project failure. The second and third pillars concern respectively early-stage and later-stage capital and notably take the form of public participation in investment funds (via public-private investment funds as well as a "fund of funds"). The aim is to mobilise private capital to close a perceived equity gap for investments of between EUR 0.2 and 3 million. The SME+ fund is designed as a "revolving fund", where on average about $80 \%$ of the invested money should return for new investments. It is open to the entire private sector, though part of its spending is earmarked for the top sector "creative industry". 
Figure 13. Excellent research system but mediocre business linkages

The scale of the indicator is $0-1$, from lowest maximum possible performance

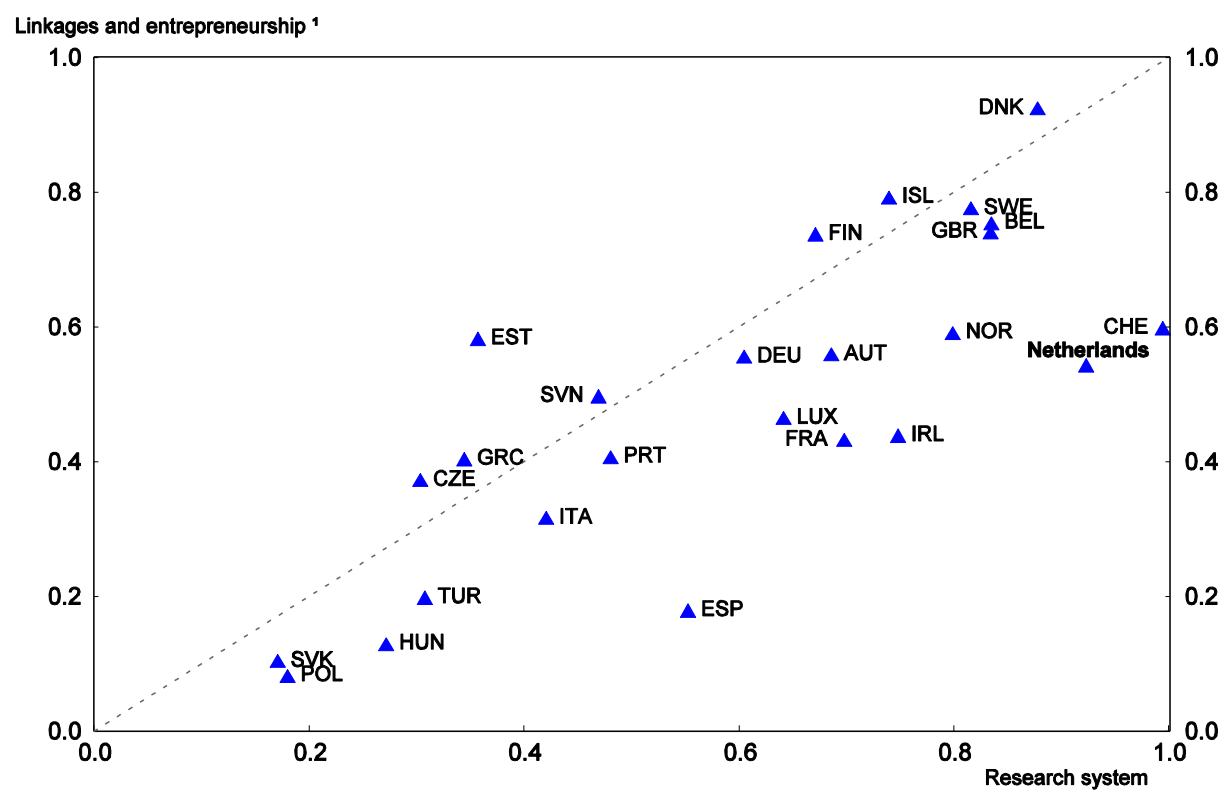

1. Linkages and entrepreneurship concerns the items: Public-private co-publications per million population. Innovative SMEs collaborating with others as per cent of SMEs; SMEs innovating in-house as percent of SMEs. Research system concerns the items: International scientific co-publications per million population; Scientific publications among the top $10 \%$ most cited publications worldwide as percent of total scientific publications of the country; Non-EU doctorate students as a percent of all doctorate students.

Source: European Commission (2011), Innovation Union Scoreboard 2010.

The new SME+ innovation fund has the potential to contribute to the development of the (small) venture capital market, which is often a key financial source for innovations (Figure 14) (Van Ark et al., 2009). Indeed, venture capitalists bring sector specific knowledge, access to relevant networks and may help raising additional financing at a later stage (Boot and Schmeits, 2004; Da Rin et al., 2005). Moreover, the fund is complementary to the innovation tax credits, which benefit relatively less to young innovative SMEs (as these firms often lack taxable income). However, there are several risks to the approach. First, the targeted recovery rate on investments $(80 \%)$ risks leading the SME+ fund to avoid financing the most risky projects, even though these projects are potentially the most radically innovative. There is also a risk of crowding out private financing for the less risky projects. Another potential issue with the target recovery rate is that assessing returns on investment takes time, as investments from private venture capital funds typically take 5 to 10 years to materialise (Lerner, 2009; Murray and Lingelbach, 2009; Nesta, 2009). Moreover, there can be an issue of potentially "over-engineering" of the venture capital market, where public programmes could create artificial funding barrier between successive phases of the development of the company that requires an evolving funding process (Lerner, 2009; Nesta, 2009). Finally, deviations from the fund's generic nature - like the earmarked funding for the "creative industry" - risk hindering strict project selection. 
Figure 14. Venture capital market is relatively small

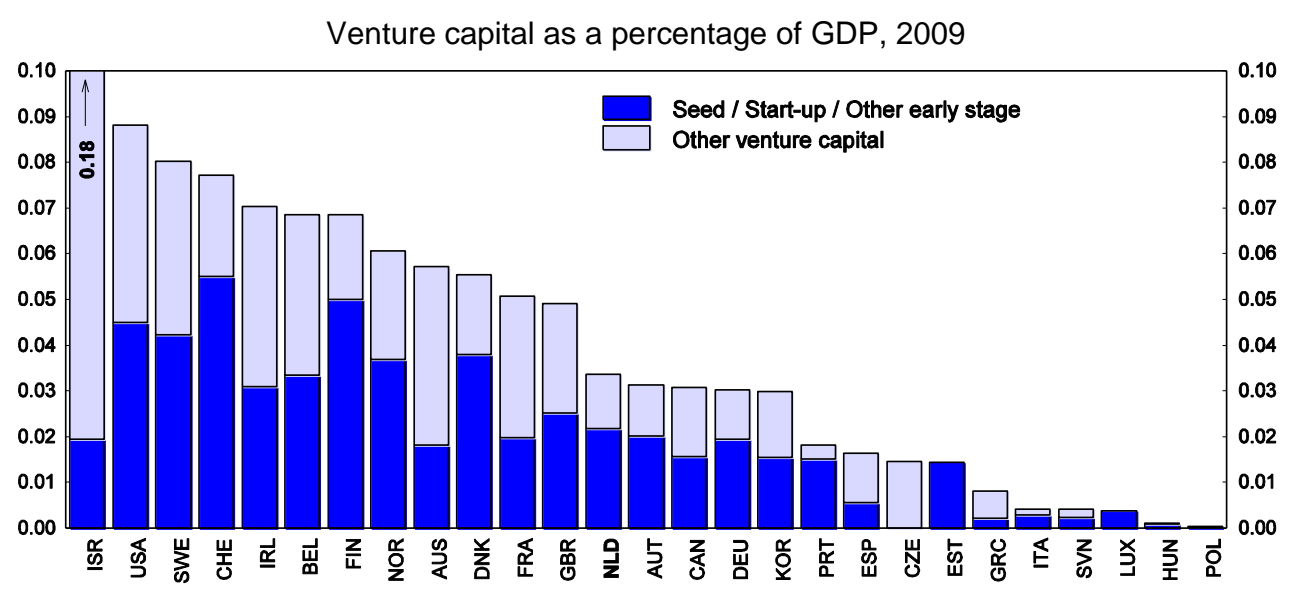

Source: OECD (2011), Entrepreneurship at a Glance.

Greater emphasis on competition policy is an area where policies to improve the business environment could be broadened. A robust competition framework supports entrepreneurship and an efficient allocation of production, and may strengthen possible positive effects of more targeted support as well as innovation (Jaumotte and Pain, 2005; OECD, 2010d; Aghion et al., 2011). In the Netherlands, unnecessarily high regulatory barriers still harm competition by discouraging new firms from entering markets, notwithstanding the relaxation of barriers to entrepreneurship since the mid 1990s (Kocsis et al., 2009). Monetary costs of starting a business and the time delay caused by entry regulations are associated with lower entry rates (Fisman and Sarria-Allende, 2009; Klapper et al., 2006; Ciccone and Papaioannou, 2007). Against this backdrop, the planned further reduction in red tape is a welcome move (Box 5) (Figure 15). Moreover, a number of network and services sectors, like retail distribution, legal services, accounting and road freight business, remain relatively sheltered from entry (Figure 16), while concentration in some sectors, such as financial and telecommunication services, is quite high. Likewise, streamlining exit procedures could further facilitate the process of creative destruction. As covered in the 2006 Survey, bankruptcy procedures in the Netherlands remain long and costly, pointing to a need for reform. Hence, the new policies for the business sector should be broadened by giving greater attention to competition policies, in particular to lower entry and exit barriers.

\section{Box 5. Reducing red tape}

The economic agenda has ambitious targets to reduce the administrative burden for businesses (Ministry of EL\&I, 2011a). Based on Standard Cost Model calculations - a method for measuring and pricing the administrative burden imposed by regulation by assessing time spend on compliance - the burden has to decrease by $10 \%$ in 2012 (compared to 2010) and by an annual 5\% in the years after. The targets are a continuation of the significant reductions of administrative burdens over the latest decade (OECD, 2010c). Besides cutting red tape, the government aims at reducing compliance and supervisory costs as well as improving government services. The specific measures include simplifying payroll taxes, reducing bureaucracy formalities for starting limited private companies, scrapping chambers of commerce levies, lowering reporting requirements (such as tax returns and financial statements), creating an administrative "one-stop-shop" for all entrepreneurs and reducing inspection for companies that consistently comply with existing rules. Better regulation is an important contribution to improve broad framework conditions. 
Figure 15. Administrative burdens on start-up

The scale of the indicator is 0-6 from least to most restrictive, 2008

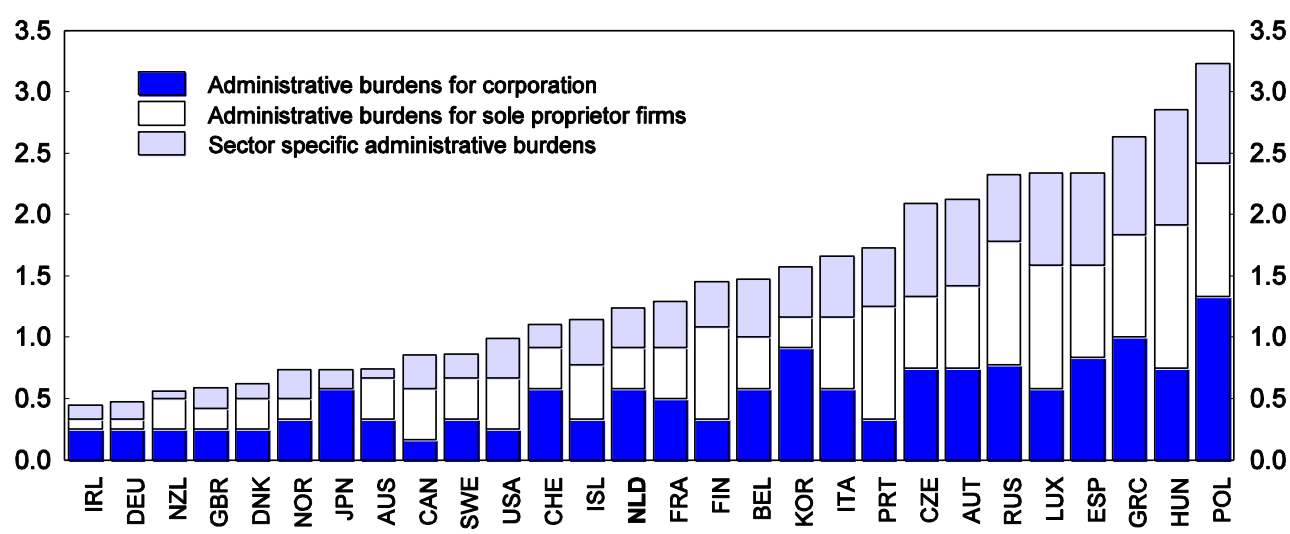

Source: OECD (2011), Product Market Regulation Database, www.oecd.org/economy/pmr.

Figure16. Entry regulation for a selection of sectors

The scale of the indicator is $0-6$ from least to most restrictive, $2008^{1}$

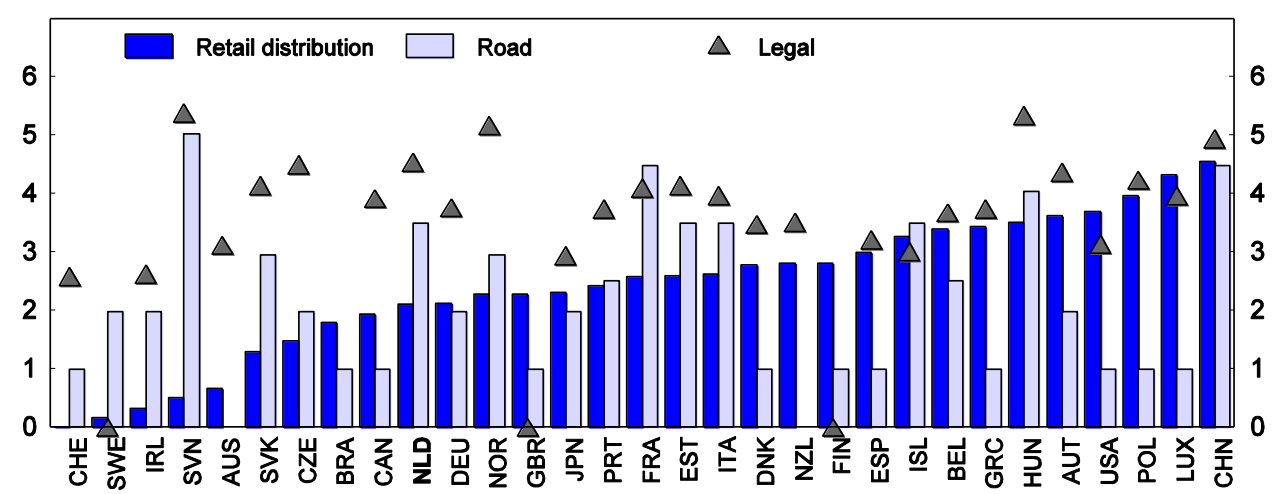

1. 2007 for Road.

Source: OECD (2011), Product Market Regulation Database, www.oecd.org/economy/pmr.

The different elements of the economic agenda are likely to improve framework conditions, which - together with stronger competition policies - should foster entrepreneurial activity. However, business policies cannot be a standalone measure, particularly if the Netherlands is to reach the government's ambition of becoming one of the top five knowledge economies by 2020 (see Box. 2). Surveys notably point to problems with the labour market and tax issues (Table 4; OECD, 2012), areas that receive far less attention in the new policies for the business sector. Reforms that increase the flexibility of the Dutch labour market would be complementary to the new business policy, as such reforms are likely to foster innovative activities and the diffusion of knowledge (Bovenberg and Theeuwes, 2004). High-risk innovative sectors tend to be smaller in countries, like the Netherlands, with strict employment protection legislation (Bartelsman et al., 2010). Also, more flexible labour markets lower the necessary wage premium to attract high skilled workers to fast growing sectors (Van Ark et al., 2009). A related issue is that there are relatively few "growth-oriented" innovative SMEs in the Netherlands; an observation that is in part linked to labour market rigidities and the high protection of workers (e.g. Stam and Gerritsen, 2009; OECD 2010d; AWT, 2011) (Figure 17). Hence, the policies to improve the business sector environment should be backed by reforms that address labour market rigidities. 
Table 4. Top 10 problematic factors for doing business in the Netherlands

\begin{tabular}{|c|c|c|c|c|c|}
\hline & World Economic Forum ${ }^{1}$ & & $\begin{array}{l}\text { Business climate survey } \\
\text { Ernst and Young }\end{array}$ & & Employer organisations $^{3}$ \\
\hline 1 & Restrictive labour regulations & 1 & Labour costs & 1 & Labour market flexibility \\
\hline 2 & $\begin{array}{l}\text { Inefficient government } \\
\text { bureaucracy }\end{array}$ & 2 & Real estate costs & 2 & Legal obligations entrepeneurship ${ }^{4}$ \\
\hline 3 & Access to financing & 3 & Labour market flexibility & 3 & Administrative burden wage bill \\
\hline 4 & Tax rates & 4 & Tax benefits and subsidies & 4 & Access to financing \\
\hline 5 & Inadequately educated workers & 5 & $\begin{array}{l}\text { Availability and quality of } \\
\text { R\&D }\end{array}$ & 5 & $\begin{array}{l}\text { Barriers to international trade and } \\
\text { investment }\end{array}$ \\
\hline 6 & Tax regulations & 6 & Expertise in own industry & 6 & Innovation policy \\
\hline 7 & $\begin{array}{l}\text { Inadequate supply of } \\
\text { infrastructure }\end{array}$ & & & 7 & Procurement: SME involvement \\
\hline 8 & $\begin{array}{l}\text { Poor work ethic in national } \\
\text { labour force }\end{array}$ & & & 8 & Zoning and planning regulation \\
\hline 9 & Inflation & & & 9 & Local supervisory burden \\
\hline 10 & Policy instability & & & 10 & Local licence and permits system \\
\hline
\end{tabular}

1. From a list of 15 factors, respondents were asked to select the five most problematic for doing business in their country and to rank them between 1 (most problematic) and 5.

2. Based on share of respondents (among key players in internationally operating firms) that judge the mentioned elements of the business climate "little attractive", or not attractive at all.

3. Top 10 business bottlenecks that hamper companies to expand according to MKB-Nederland and VNO-NCW.

4. For instance, mandatory wage payments for workers who are sick or disabled beyond the control of the employer.

Source: World Economic Forum (2011), Ernst and Young - Barometer Nederlands vestigingsklimaat (2011), Ministry of Economic Affairs, Agriculture and Innovation - Zelfstanding ondernemerschap (2009).

\section{Figure 17. Fast growing (innovative SME) enterprises}

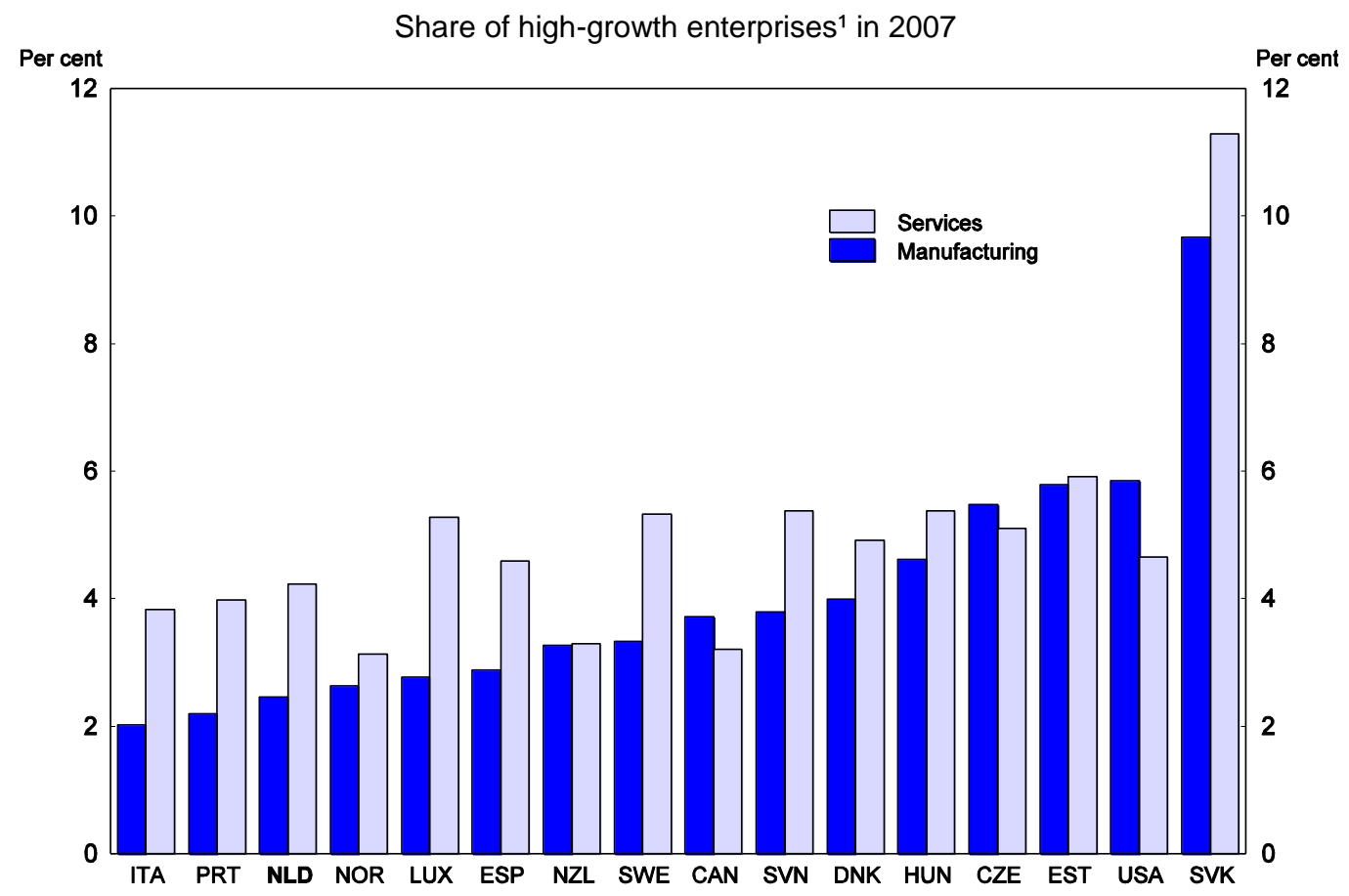

1. The share of high-growth enterprises is compiled as the number of high-growth enterprises as a percentage of the population of enterprises with ten or more employees, 2006 for Norway.

Source: OECD (2011), Entrepreneurship at a Glance. 
Box 6. Recommendations to strengthen the business environment

\section{Broaden targeted support to different sectors}

- The scope of the top sectors should be more clearly defined in order to ensure an efficient use of public funds and enable evidence-based policy making.

- To take full advantage of the top team approach to improve sector regulation, similar teams should be created for more sectors of the economy, especially services.

- The government should ensure that the funds earmarked to top sectors in the area of research do not become a vehicle for favouring particular firms, especially as incumbents may benefit from a first mover advantage.

- The top sector approach should remain open to future emerging sectors and industries as well as to let any declining ones go. A swift and broad implementation of the planned move towards evidence-based policy-making would facilitate future sector selection.

- Regarding economic diplomacy, the public services offered should reflect at least some of the costs, in order to secure the cost-efficient use of scarce public resources.

\section{Further enhance framework conditions}

- The stability of the new R\&D support framework should be backed by long-term political commitment to support firms' multi-year research programmes.

- $\quad$ The R\&D support framework should be simplified by reducing the number of tax credits.

- To strengthen the relatively weak science-business linkages, researchers' incentives to market the results of their research should be enhanced by establishing clear and more generous rules for sharing patents rights.

- The government should further promote framework conditions by giving greater attention to competition policies. In particular, lower entry and exit barriers will support the process of "creative destruction".

- $\quad$ The policies to improve the business sector environment should be backed by reforms that address labour market rigidities. 


\section{BIBLIOGRAPHY}

Aghion, P., J. Bulanger and E. Cohen (2011), "Rethinking Industrial Policy”, Breugel Policy Brief, Issue 2011/04, June.

AWT (2011), “Kapitale kansen”, February, Zoetermeer.

Baldwin, R. (2006), "Globalisation, the great unbundling(s)", Secretariat of the Economic Council, Finnish Prime Minister's Office, Helsinki.

Barbour, V. (1950), Capitalism in Amsterdam in the Seventeenth Century, Johns Hopkins Press, Baltimore.

Bartelsman, E.J., P.A. Gautier and J. de Wind (2010), "Employment Protection, Technology Choice, and Worker Allocation", TI 2010-042/3, Tinbergen Institute Discussion Paper, Amsterdam/ Rotterdam.

Bernard, A. B., J. Bradford Jensen, S.J. Redding and P.K. Schott (2007), "Firms in international trade", Journal of Economic Perspectives, Vol. 21, No. 3.

Boot, A. and A. Schmeits (2004), "Imperfecties in de vermogensmarkt en overheidsbeleid". In: Innovatie in Nederland: De markt draalt en de overheid faalt, Koninklijke Vereniging voor de Staathuishoudkunde, Preadviezen.

Bos, J. and E. Stam (2011), "Gazelles, Industry Growth and Structural Change”, Tjalling C. Koopmans Research Institute, Discussion Paper Series 11-02, Utrecht.

Bovenberg, L. and J. Theeuwes (2004), “Arbeid en Innovatie” In: Innovatie in Nederland: De markt draalt en de overheid faalt, Koninklijke Vereniging voor de Staathuishoudkunde, Preadviezen.

Ciccone, A. and E. Papaioannou (2007), "Red Tape and Delayed Entry", Journal of the European Economic Association April-May, 5(2-3).

Cornet, M., F. Huizinga, B. Minne and D. Webbink (2006), “Kansrijk kennisbeleid”, CPB Document No. 124, Centraal Planbureau, The Hague.

Court of Audit (Algemene Rekenkamer) (2011), "Innovatiebeleid”, Algemene Rekenkamer, September 28, The Hague.

CPB (2010), Keuzes bij innovatiebeleid: Bouwstenen voor heroverwegingswerkgroep Innovatie en Toegepast Onderzoek. 2010/13.

CPB (2011), Reactie op Research en Development aftrek, CPB notitie, Centraal Planbureau, The Hague.

Creusen, H., and A. Lejour (2011), "Uncertainty and the Export Decisions of Dutch Firms”, CPB Discussion Paper No. 183, Centraal Planbureau, The Hague.

Criscuolo, C., D. Czarnitzki, C. Hambro and J. Warda (2009), "Design and Evaluation of Tax Incentives for Business Research and Development: Good Practice and Future Development", Final report submitted by the Expert Group on Impacts of R\&D Tax Incentives to the European Commission, Directorate General - Research, November 15. 
Da Rin, M., G. Nicodano and Alessandro Sembenelli (2005), "Public Policy and the Creation of ActiveVenture Capital Markets". ECB Working Paper Series, No. 430. European Central Bank,Frankfurt am Main.

De Graaf, D., A. Heyma and C. van Klaveren (2007), "De arbeidsmarkt van hoger opgeleide bèta's", SEO-rapport No. 992, Amsterdam.

DNB (De Nederlandsche Bank) (2007), "Dutch competitiveness in international services trade", Quarterly Bulletin, December, Amsterdam.

DNB (De Nederlandsche Bank) (2008), Statistical Bulletin, September, Amsterdam.

DNB (De Nederlandsche Bank) (2011), "Netherlands Leads the Field in Direct Investment", DNB Bulletin, August, Amsterdam.

EIM (2011), "Analyse sectorstructuur en private R\&D: Verklaring van de relatieve positie van Nederland", Zoetermeer.

Erken, H.P.G. and M.L. Ruiter (2005), "Determinanten van de private R\&D-uitgaven in internationaal perspectief", Ministry of Economic Affairs and Dialogic, The Hague.

Ernst \& Young (2011), Barometer Nederlands vestigingsklimaat.

Gelauff, G., A. van der Horst and B. ter Weel (2010), “The Netherlands of 2040”, CPB Document No. 88, Centraal Planbureau, The Hague.

Gorter, J., P. Tang and M. Toet (2005), "Verplaatsing vanuit Nederland”, CPB Document No. 76, Centraal Planbureau, The Hague.

Government (2010), Innovatie en Toegepast Onderzoek. Rapport brede heroverwegingen; The Netherlands, The Hague, April.

Government (2012), “Aanbieding Samenvatting Innovatiecontracten en Human Capital Agenda's”, Letter By the Chairmen of the Top Teams to the Minister of Economic Affairs, Agriculture and Innovation, January, The Hague.

Groot, S.P.T., A. Lejour and M. Gerritsen (2011a), "Uitvoer Naar Opkomende economieën”, Economische Statistische Berichten, 96(4601).

Groot, S.P.T, H.L.F. de Groot, A.M. Lejour and J. Möhlmann (2011b), "The rise of the BRIC countries and its impact on the Dutch economy", CPB Background document, Centraal Planbureau, The Hague.

Guellec, D. and B.Van Pottelsberghe De La Potterie (2003): The impact of public R\&D expenditure on business R\&D, Economics of Innovation and New Technology, 12:3, 225-243.

Fisman, R., and V. Sarria Allende (2009), "Regulation of Entry and the Distortion of Industrial Organization", Journal of Applied Economics. Vol. XIII, No. 1, May.

Harris, R. and Q. Cher Li (2005), "Review of the Literature: The Role of International Trade and Investment in Business Growth and Development", Report to UK Trade and Investment.

Heyma, A. and J. Theeuwes (2008), “Offshoring and the Worker”, SEO-report 2007-94, Amsterdam. 
Jacobs, B. and D. Webbink (2004), “Onderwijs, innovatie en productiviteit” In: Innovatie in Nederland: De markt draalt en de overheid faalt, Koninklijke Vereniging voor de Staathuishoudkunde, Preadviezen.

Jacobs, B. and J. Theeuwes (2004), Innovatie in Nederland: De Markt Draalt en de Overheid Faalt, Koninklijke Vereniging voor de Staathuishoudkunde Preadviezen, Amsterdam.

Jaumotte, F. and N. Pain (2005), "Innovation in the Business Sector", OECD Economics Department Working Papers, No. 459, OECD Publishing.

Klapper, L., L. Laeven and R. Rajan (2006), “Entry regulation as a barrier to entrepreneurship”, Journal of Financial Economics 82.

Kocsis V., R.Lukach, B. Minne, V.Shestalova, N. Zubanov and H. van der Wiel (2009), "Relation Entry, Exit and Productivity. An Overview of Recent Theoretical and Empirical Literature", CPB Document No. 180, Centraal Planbureau, The Hague.

Koster, S., and Arjen Edzes (2011), “Topsectoren behoeven eenduidige definiëring”, Economische Statistische Berichten, 96(4601).

Kranendonk, H. and J. Verbruggen (2011), "Het belang van uitvoer en binnenlandse bestedingen voor productie en werkgelegenheid in Nederland", Achtergronddocument bij CEP, Centraal Planbureau, The Hague.

Krugman, P. (1994), “Competitiveness: A Dangerous Obsession”, Foreign Affairs, Vol. 73 No. 2, March/April.

Kuypers, F., A. Lejour, O. Lemmers and P. Ramaekers (2012), "Kenmerken van Wederuitvoerbedrijven”, Centraal Planbureau/ Centraal Bureau Voor de Statistiek, The Hague/ Heerlen.

Lanser, D. and H. van der Wiel (2011). "Innovatiebeleid in Nederland: De (on)mogelijkheden van effectmeting". CPB achtergronddocument. Centraal Planbureau, The Hague.

Lerner, J. (2009), "Boulevard of Broken Dreams: Why Public Efforts to Boost Entrepreneurship and Venture Capital Have Failed--and What to Do About It", Princeton University Press

Lin, J. and H-J. Chang (2009), "Should Industrial Policy in Developing Countries Conform to Comparative Advantage or Defy it? A Debate Between Justin Lin and Ha-Joon Chang,Development Policy Review, 27(5).

Maastricht Economic and Social Research Institute on Innovation and Technology (2011), European Commission, Innovation Union Scoreboard, February.

Mellens, M.C., H.G.A. Noordman and J.P. Verbruggen (2007), "Re-exports: International comparison and implications for performance indicators", CPB Document No 143, Centraal Planbureau, The Hague.

Ministry of Economic Affairs (2009), “Zelfstandig ondernemerschap”, September, The Hague.

Ministry of Economic Affairs, Agriculture and Innovation (EL\&I) (2011a), "To the Top. Towards a New Enterprise Policy", February, The Hague.

Ministry of Economic Affairs, Agriculture and Innovation (EL\&I) (2011b), "To the Top, the Enterprise Policy in Action(s)", September, The Hague.

Ministry of Economic Affairs, Agriculture and Innovation (EL\&I) (2011c), "Buitenlandse Markten, Nederlands kansen", June, The Hague. 
Ministry of Economic Affairs, Agriculture and Innovation (EL\&I) (2011d), "Rijksbreed overzicht innovatiemiddelen", October, The Hague.

Ministry of Economic Affairs, Agriculture and Innovation (EL\&I) (2011e), "Naar een gezonde basis: bedrijfsfinanciering na de crisis", Advies van de expertgroep bedrijfsfinanciering op verzoek van de minister van Economische Zaken, Landbouw en Innovatie, June, The Hague.

Ministry of Economic Affairs, Agriculture and Innovation (EL\&I) (2012), "Eerste Reactie op Innovatiecontracten en Human Capital Agenda's van de Topsectoren.”, January, The Hague.

Moons, S. and P. van Bergeijk (2011), "De Effectiviteit van Economische Diplomatie”, Economische Statistische Berichten, 96(4616).

Murray, G. and D. Lingelbach (2009), “Twelve Meditations on Venture Capital: Some Heretical Observations on the Dissonance between Theory and Practice When Applied to Public/Private Collaborations on Entrepreneurial Finance Policy", University of Exeter Business School, Working Paper No. 09/06.

Naudé, W. (2010a), Industrial Policy, Working paper No.2010/106, United Nations University, World Institute for Development Research.

Naudé, W. (2010b), New Challenges for Industrial Policy, Working paper No. 2010/107, United Nations University, World Institute for Development Research.

Nesta (2009): "From funding gaps to thin markets, UK Government support for early-venture capital", Research report, with BVCA.

NFIA (2011), “Why Invest in Holland?”, Netherlands Foreign Investment Agency, January.

Noailly J., D.Waagmeester, B.Jacobs, M.Rensman and D.Webbink (2005), "Scarcity of science and engineering students in the Netherlands", CPB Document No. 192, Centraal Planbureau, The Hague.

Nicoletti G., S. Golub, D.Hajkova, D.Mirza and. K.-Y. Yoo (2003), "Policies and International Integration: Influences on Trade and Foreign Direct Investment", OECD Economics Department Working Papers, No. 359, OECD Publishing.

OECD (2005), "Growth in Services - Fostering Employment, Productivity and Innovation", OECD Digital Economy Papers, No. 94, OECD Publishing.

OECD (2006a), Going for growth, OECD Publishing.

OECD (2006b), “The SME Financing Gap", 2006, OECD Publishing.

OECD (2007a), Staying Competitive in the Global Economy, Moving up the Value Chain, OECD Publishing.

OECD (2007b), "Making the Most of Globalisation", OECD Economic Outlook, Chapter 3, Vol. 2007/1, No. 81, June, OECD Publishing.

OECD (2010a), OECD Economic Survey of Germany, OECD Publishing.

OECD (2010b), The OECD Innovation Strategy: Getting a head start on tomorrow, OECD Publishing.

OECD (2010c), Better Regulation in Europe: Netherlands, 2010, OECD Publishing. 
OECD (2010d), “The Role of High Growth Firms in Catalysing Entrepeneurship and Innovation”, OECD Publishing.

OECD (2011a), "Fostering New Sources Of Growth - Is There a Role For "Industrial" Policy in the $21^{\text {st }}$ Century?", Background Paper, STI/IND/AH(2011)1, OECD Publishing.

OECD (2011b), “Tax Reform Options: Incentives for Innovation. The International Experience with R\&D Tax Incentives", Testimony by the OECD, United States Senate Committee on Finance, September 20.

OECD (2011c), OECD Observer No 284, Q1, OECD Publishing.

OECD (2011d), "New Sources of Growth: Intangible Assets, Preliminary Evidence and Policy Issues", DSTI/IND(2011)2, OECD Publishing.

OECD (2012), Economic Survey of the Netherlands

Pain, N., I. Koske and M. Sollie (2008), “Globalisation and OECD Consumer Price Inflation”, OECD Economic Studies No. 44, 2008/1.

Port of Rotterdam Authority (2011a), Haven in Cijfers, May, Rotterdam.

Port of Rotterdam Authority (2011b), Annual Report 2010, Rotterdam.

Port of Rotterdam Authority (2011c), Port Compass: Port Vision 2030, December, Rotterdam.

Rae, D. and M. Sollie (2008), "Globalisation and the European Union: Which Countries are Best Placed to Cope?", OECD Economics Department Working Paper No. 586.

Rodrik, D. (2008), "Normalizing Industrial Policy”, Commission on Growth and Development Working Paper, No. 3, Washington DC.

Schmidt-Ehmcke, J. and P. Zloczysti (2011), Industries at the Wold Technology Frontier: Measuring R\&D Efficiency in a Non-Parametric DEA Framework, GRASP Working Paper 16, August.

Sociaal-Economische Raad (SER) (2008), "On sustainable globalisation: A world to be won.” Advisory report. Sociaal-Economische Raad, The Hague.

Stam, E. and D. Gerritsen (2009), “Gazellen in de Lage Landen”, Universiteit Utrecht.

Statistics Netherlands (2008), "Internationaliseringsmonitor 2008”, The Hague.

Statistics Netherlands (2009), "Internationalisation Monitor 2009“, The Hague.

Statistics Netherlands (2010a), "Internationalisation Monitor 2010“, The Hague.

Statistics Netherlands (2010b), "Helft Nederlandse internationale handel door buitenlandse bedrijven", Web magazine, November.

Statistics Netherlands (2010c), "Half of Dutch good exports to Germany manufactured in the Netherlands", Web magazine, June.

Statistics Netherlands (2011), "Internationalisation Monitor 2011”, The Hague. 
Suyker, W., H. L.F. de Groot and P. Buitelaar (2007), "India and the Dutch economy: Stylised facts and prospects", CPB Document No. 155, Centraal Planbureau, The Hague.

Top team Head Offices (2011), Met Hoofdkantoren Naar de Top, June.

Urlings, N., F. Fortanier and M. Korvorst (2011), "Inkomende investeringen en werkgelegenheid in Nederland", Statistics Netherlands, The Hague/ Heerlen.

Van Ark, B., J. X. Hao, C. Corrado and C. Hulten (2009), "Measuring intangible capital and its contribution to economic growth in Europe", In: R\&D and the financing of innovation in Europe, EIB Papers, Vol. 14 No. 1.

Van Bergeijk, P.A.G., F. Fortanier, H.Garretsen, H.L.F. de Groot and S.J.V. Moons (2011), "Productivity and Internationalization: A Micro-Data Approach", De Economist 159, pp. 381-388.

Van den Berg, M., M. de Nooij, H. Garretsen and H.L.F. de Groot (2008), "Een onderzoek naar de maatschappelijke kosten en baten van het financieel buitenlandinstrumentarium van het Ministerie van Economische Zaken", SEO-report No. 2008-64.

Van den Bosch, F.A.J., R.Hollen, H. W. Volberda, and M. G. Baaij (2011), "De strategische waarde van het Haven- en Industriecomplex Rotterdam voor het internationale concurrentievermogen van Nederland.

Van Gorp, D.M. (2010), "Offshoring by manufacturing and service firms in the Netherlands, Offshoring behavior in times of a financial crisis," Nyenrode Business University.

Van Gorp, D.M. (2008), "Offshoring in the Service Sector: An empirical investigation on the offshoring behavior of service firms and its influence on their foreign entry mode choice", Nyenrode Business University.

Van Nieuwkerk, M. (2006), Dutch Golden Glory, Becht Press, Haarlem.

Van Veenstra, M.L.E., M. Yakop, and P.A.G. van Bergeijk (2010), "Economic Diplomacy, the Level of Development and Trade", Discussion Papers in Diplomacy, The Netherlands Institute of International Relations, Clingendael.

Wölfl, A., I.Wanner, T.Kozluk and G.Nicoletti (2009), "Ten Years of Product Market Reform in OECD Countries: Insights from a Revised PMR Indicator”, OECD Economics Department Working Papers, No. 695, OECD Publishing.

World Economic Forum (WEF) (2011), The Global Competitiveness Report 2011-12, World Economic Forum, Geneva. 


\section{WORKING PAPERS}

The full series of Economics Department Working Papers can be consulted at www.oecd.org/eco/workingpapers/

1010 Health care reform and long-term care in the Netherlands (January 2013) by Erik Schut, Stéphane Sorbe and Jens Høj

1009 Enhancing the inclusiveness of the labour market in Belgium. (January 2013) by Jens Høj

1008. Reducing poverty in Estonia through activation and better targeting (December 2012) by Sarah Flèche and Artur Radziwill

1007. Matching skills and jobs in Estonia (December 2012) by Lilas Demmou

1006. Debt and macroeconomic stability: An overview of the literature and some empirics (December 2012) by Douglas Sutherland and Peter Hoeller

1005. Debt and macroeconomic stability: Debt and the business cycle (December 2012) by Volker Ziemann

1004. Debt and macroeconomic stability: Case studies (December 2012) by Rossana Merola

1003. Debt and macroeconomic stability (December 2012) by Douglas Sutherland, Peter Hoeller, Rossana Merola and Volker Ziemann

1002. Reducing greenhouse gas emissions in a cost effective way in Switzerland. (December 2012) by Anita Wölfl and Patrizio Sicari

1001. Strengthening innovation in the United States (November 2012) by David Carey, Christopher Hill and Brian Kahin

1000. Long-term growth scenarios (forthcoming) by Åsa Johansson, Yvan Guillemette, Fabrice Murtin, David Turner, Giuseppe Nicoletti, Christine de la Maisonneuve, Philip Bagnoli, Guillaume Bousquet and Francesca Spinelli

999. Selected aspects of household savings in Germany - evidence from micro-data (November 2012) by Christina Kolerus, Isabell Koske and Felix Hüfner

998. Improving the tax system in Indonesia (November 2012) by Jens Arnold

997. Unleashing business innovation in Canada (November 2012) by Alexandra Bibbee

996. Public policy and resource allocation: evidence from firms in OECD countries (October 2012) by Dan Andrews and Federico Cingano 


\section{ECO/WKP(2013)3}

995. Promoting SME development in Indonesia

(October 2012) by Annabelle Mourougane

994. Portugal: Rebalancing the economy and returning to growth through job creation and better capital allocation.

(October 2012) by Álvaro Pina and Ildeberta Abreu

993. Public debt, economic growth and nonlinear effects: Myth or reality?

(October 2012) by Balázs Égert

992. Choosing the pace of fiscal consolidation

(September 2012) by Lukasz Rawdanowicz

991. Tertiary education developing skills for innovation and long-term growth in Canada

(September 2012) by Calista Cheung, Yvan Guillemette and Shahrzad Mobasher-Fard

990. Trade and product market policies in upstream sectors and productivity in downstream sectors: firm-level evidence from China

(September 2012) by Maria Bas and Orsetta Causa

989. Intangible assets, resource allocation and growth: a framework for analysis

(September 2012) by Dan Andrews and Alain de Serres

988. Current account benchmarks for Turkey

(September 2012) by Oliver Röhn

987. Structural reforms to boost Turkey's long-term growth

(September 2012) by Rauf Gönenç, Oliver Röhn, Vincent Koen and Şeref Saygili

986. Tackling Turkey's external and domestic macroeconomic imbalances

(September 2012) by Oliver Röhn, Rauf Gönenç, Vincent Koen and Ramazan Karaşahin

985. Portugal: Solid foundations for a sustainable fiscal consolidation

(September 2012) by David Haugh and Stéphane Sorbe

984. Portugal: Assessing the risks around the speed of fiscal consolidation in an uncertain environment

(September 2012) by Stéphane Sorbe

983. The German labour market: preparing for the future

(September 2012) by Felix Hüfner and Caroline Klein

982. Climate change policies in Germany: make ambition pay

(September 2012) by Caroline Klein

981. Restarting the growth engine in Finland

(September 2012) by Henrik Braconier

980. Import Competition, Domestic Regulation and Firm-Level Productivity Growth in the OECD (September 2012) by Sarra Ben Yahmed and Sean Dougherty 